\title{
Alkaline-earth complexes with \\ macrocyclic-functionalised bis(phenolate)s and bis(fluoroalkoxide)s $\dagger$
}

\begin{abstract}
Joanna Hammoud, ${ }^{\text {a }}$ Fatima Abou-Khalil, ${ }^{\text {a }}$ Thierry Roisnel, ${ }^{a}$ Vincent Dorcet, ${ }^{\text {a }}$ Christophe Bour, ${ }^{b}$ Vincent Gandon, ${ }^{\text {b,c }}$ David Lebœuf, ${ }^{\mathrm{d}}$ Jean-François Carpentier ${ }^{\mathrm{a}}$ and Yann Sarazin ${ }^{\mathrm{a} *}$
\end{abstract}

${ }^{a}$ Univ Rennes, CNRS, ISCR (Institut des Sciences Chimiques de Rennes) - UMR 6226, F-35000 Rennes, France.

${ }^{\mathrm{b}}$ Institut de Chimie Moléculaire et des Matériaux d'Orsay (ICMMO), CNRS UMR 8182, Université ParisSud, Université Paris-Saclay, Bâtiment 420, 91405 Orsay cedex, France

c Laboratoire de Chimie Moléculaire (LCM), CNRS UMR 9168, Ecole Polytechnique, Institut Polytechnique de Paris, route de Saclay, 91128 Palaiseau cedex, France.

${ }^{\mathrm{d}}$ Institut de Science et d'Ingénierie Supramoléculaires (ISIS), CNRS UMR 7006, Université de Strasbourg, 8 allée Gaspard Monge, 67000 Strasbourg, France

Corresponding author: yann.sarazin@univ-rennes1.fr

$\dagger$ Electronic supplementary information (ESI) available: synthetic and analytical details, NMR spectra and crystallographic data for CCDC 1995095-1995102, 2009320, 2009385, 2009421 and 2009437. 


\begin{abstract}
The synthesis and structural features of several families of unsolvated molecular complexes of the heavy alkaline earths $(\mathrm{Ae}=$ calcium, strontium and barium) supported by bis(phenolate)s or bis(fluoroalkoxide)s are described. These dianionic, multidentate ligands are built around diaza-macrocycles that contain either five or six N- and O-heteroatoms. Several of these complexes have been characterised by X-ray diffraction crystallography. A list of comparative features was drawn upon close examination of the molecular structures of these complexes. It highlights the subtle influences of the identity of the central Ae metal, denticity and nature -fluoroalkoxide vs phenolate- of the anionic tethers in the ligands. All complexes are seven- or eight-coordinate. It is observed in particular that a decrease of the number of heteroatoms in the macrocyclic backbone of the ligand will be compensated by the establishment of intramolecular Ae $\cdots \mathrm{F}$ interactions (accounting for ca. 3.8-6.4\% of the pertaining coordination spheres according to bond valence sum analysis), dimerisation of the complex, or, in one case, solvent (thf) retention. Attempts to gauge the Lewis acidity in these series of complexes were carried out by three independent methods (Childs, GutmannBeckett and global electrophilicity index). However, conflicting results were obtained and no clear trend can be delineated, even if on the whole, these measurements concur to suggest relatively low Lewis acidity.
\end{abstract}




\section{Introduction}

As a sign of the interest that $s$-block metal chemistry has been raising in the past decade, discrete complexes of the abundant and inexpensive calcium and heavier alkaline earths strontium and barium $(\mathrm{Ae}=\mathrm{Ca}, \mathrm{Sr}$, $\mathrm{Ba}$ ) are increasingly attracting attention as homogeneous catalysts for a growing array of organic transformations. ${ }^{1}$ What initially started off as an original utilisation of calcium compounds in polymerisation catalysis $^{2-3}$ has now developed into comprehensive research programs, where Ae species display a specific reactivity of their own paired with impressive reaction rates in molecular catalysis. Reactions competently promoted by Ae complexes include the hydroamination, ${ }^{4-5}$ hydrogenation ${ }^{6}$ and hydrosilylation ${ }^{7}$ of alkenes, hydrophosphination of alkynes $^{8}$ and alkenes, ${ }^{9}$ and E-E' heteroatom bond formation through heterodehydrocouplings. ${ }^{10}$ A variety of (selected) other Ae-mediated processes can be cited, e.g. arene alkylation and heterolytic $\mathrm{H}_{2}$ cleavage, ${ }^{11}$ B-N bond formation thorough desilacoupling, ${ }^{12} \mathrm{CO}$ functionalisation, ${ }^{13}$ and uses towards hydrogen storage materials. ${ }^{14}$ In addition to well-defined Ae complexes, soluble calcium salts, and amongst these most prominently calcium bis(triflimidate) (= $\left.\mathrm{Ca}\left(\mathrm{NTf}_{2}\right)_{2}\right)$, have emerged as potent Lewis acid catalysts for a large range of cyclisation reactions and unsaturated carbon-carbon bond functionalisations. ${ }^{15}$

Together with other research groups, we have been keen on implementing alkaline-earth complexes in molecular catalysis, ${ }^{1}$ and, along the way, we have been led to develop original ancillary ligands that enable a fine control of the first coordination sphere around the $\mathrm{Ae}^{2+}$ cation. We have shown that monoanionic, side-functionalised aminoether-phenolates are able to kinetically inhibit Schlenk equilibria and hence generate potent heteroleptic Ae precatalysts. ${ }^{16}$ Fluoroalkoxides bearing electron-withdrawing $\mathrm{CF}_{3}$ groups in $\alpha$ position of the alkoxide have been shown to tame the propensity to produce insoluble aggregated Aealkoxides, and instead generate soluble Ae complexes of low nuclearity. ${ }^{17}$ As a result, the clean synthesis of soluble, heteroleptic Ae-aminofluoroalkoxide dimers has returned various families of precatalysts and model compounds. ${ }^{18}$ In particular, the incorporation of aza-crown-ether tethers in the proligand, as in the phenol 1-H and the fluoroalcohol 2-H depicted in Figure 1, has provided an effective tool to obtain stable Ae complexes from the corresponding anionic ligands. Besides, calcium bis(phenolate)s have proved efficient catalysts for the ring-opening polymerisation of cyclic esters. ${ }^{2 d, 19} \mathrm{We}$ surmised that $N, O$ macrocycles could be utilised as a core to construct dianionic phenoxides and fluoroalkoxides that would in turn enable the synthesis of Ae complexes potentially useful as Lewis acids. In this context, we report here the preparation and characterisation of alkaline-earth complexes supported by dianionic ligands emanating from $3-\mathrm{H}_{2} / 6-\mathrm{H}_{2}$. Structural features and attempts to gauge their respective Lewis acidity are also discussed. 

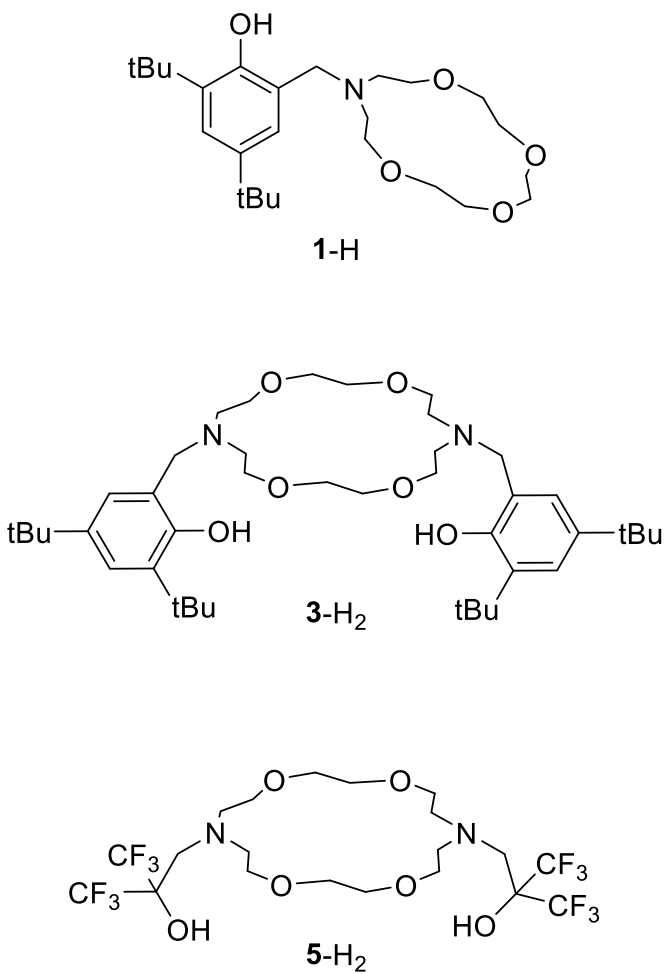

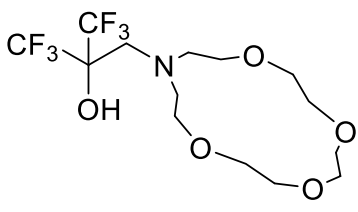

2-H
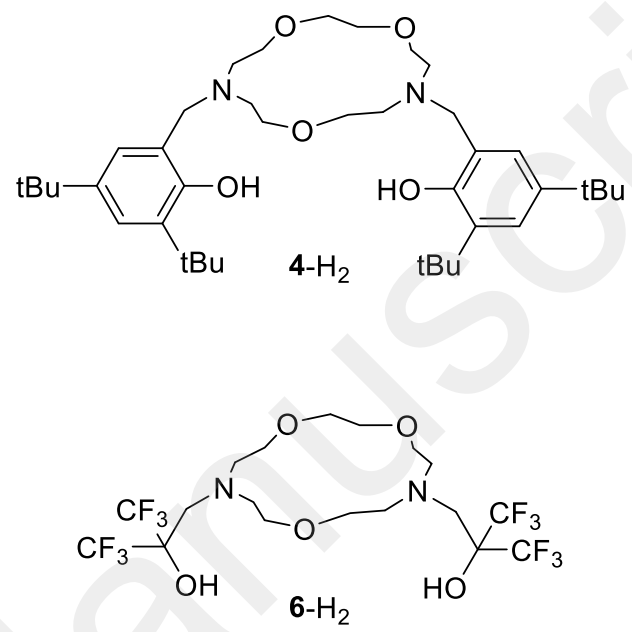

Figure 1. Known (1-H and 2-H $)^{16-18}$ and new $\left(3-\mathrm{H}_{2}\right.$ to $\left.6-\mathrm{H}_{2}\right)$ proligands bearing macrocyclic cores for the synthesis of molecular alkaline-earth complexes. 


\section{Results and Discussion}

The two bisphenol proligands $\left\{\left(\mathrm{N}_{2} \mathrm{O}_{4}\right) \mathrm{Ar}_{2} \mathrm{O}_{2}\right\} \mathrm{H}_{2}$ and $\left\{\left(\mathrm{N}_{2} \mathrm{O}_{3}\right) \mathrm{Ar}_{2} \mathrm{O}_{2}\right\} \mathrm{H}_{2}$, aka $3-\mathrm{H}_{2}$ and $4-\mathrm{H}_{2}$ in Figure 1, that respectively incorporate 6- and 5-member diaza macrocyclic cores, were isolated in 45-50\% yield following the Mannich condensation between 2,4- $-\mathrm{Bu}_{2}-\mathrm{C}_{6} \mathrm{H}_{3} \mathrm{OH}$, formaldehyde and the corresponding diaza-crownether in refluxing methanol (Scheme 1). They are sparingly soluble in $\mathrm{Et}_{2} \mathrm{O}$ and toluene, but dissolve easily in chlorinated solvents and thf. The fluoroalcohols $\left\{\left(\mathrm{N}_{2} \mathrm{O}_{4}\right) \mathrm{R}_{2} \mathrm{O}_{2}\right\} \mathrm{H}_{2}$ and $\left\{\left(\mathrm{N}_{2} \mathrm{O}_{3}\right) \mathrm{R}_{2} \mathrm{O}_{2}\right\} \mathrm{H}_{2}$, that is, 5- $\mathrm{H}_{2}$ and 6- $\mathrm{H}_{2}$ in Figure 1, were obtained in high yields (85-90\%) by reacting the diaza-crown-ethers with 2,2bis(trifluoromethyl)oxirane at room temperature in $\mathrm{Et}_{2} \mathrm{O}$. They are very soluble in all common organic solvents, including aliphatic hydrocarbons. All four proligands were isolated as colourless solids, and they were recrystallised as single-site crystals suitable for X-ray diffraction analysis from concentrated methanol solutions. Their molecular structures are given with selected metric parameters in the Supporting Information (S10-S13). The identity of all proligands was corroborated by NMR spectroscopy and HR mass spectrometry, and their purity was confirmed by combustion analyses. The ${ }^{1} \mathrm{H}$ NMR spectra of the bis(phenol)s $3-\mathrm{H}_{2}$ and $4-\mathrm{H}_{2}$ recorded in benzene- $d_{6}$ at room temperature are well resolved. The resolution in the ${ }^{1} \mathrm{H}$ NMR spectra for the corresponding fluoroalcohols $\mathbf{5}-\mathrm{H}_{2}$ and $\mathbf{6}-\mathrm{H}_{2}$ is lower, but all resonances remain assignable without ambiguity. Their ${ }^{19} \mathrm{~F}$ NMR spectra in benzene- $d_{6}$ at room temperature exhibit a sharp singlet at -77.13 and $-77.19 \mathrm{ppm}$, respectively. The coupling between $\mathrm{C}$ and $\mathrm{F}$ atoms in the fluoroalcohols is readily detected in their ${ }^{13} \mathrm{C}\left\{{ }^{1} \mathrm{H}\right\}$ NMR spectra. For instance, the $\alpha$ and $\beta$ carbon atoms in $5-\mathrm{H}_{2}$ give rise to a quadruplet $\left({ }^{1} J_{\mathrm{C}-\mathrm{F}}=288 \mathrm{~Hz}\right)$ and a heptet $\left({ }^{2} J_{\mathrm{C}-\mathrm{F}}=28 \mathrm{~Hz}\right)$ centred respectively on 125.97 and $73.62 \mathrm{ppm}$.

All new proligands were reacted with half an equivalent of the thf-solvated alkaline-earth precursors $\left[\mathrm{Ae}\left\{\mathrm{N}\left(\mathrm{SiMe}_{3}\right)_{2}\right\}_{2} \cdot(\text { thf })_{2}\right](\mathrm{Ae}=\mathrm{Ca}, \mathrm{Sr}$ and $\mathrm{Ba} ;$ Scheme 1$)$. The reactions were usually carried out in $\mathrm{Et}_{2} \mathrm{O}$, although in some cases 1,2-difluorobenzene was used when the solubility of the proligand was troublesome and the use of thf was avoided. Hence, the families of complexes 3-Ae to 6-Ae were synthesised free of coordinated solvent upon release of thf and two equivalents of $\mathrm{HN}\left(\mathrm{SiMe}_{3}\right)_{2}$. They were isolated as colourless solids in good yields, generally in the range $60-80 \%$. Many of these complexes were also recrystallised as single crystals suited to X-ray diffraction studies (see below). One complex stands out in this series. The strontium 6-Sr, obtained in moderate yield (52\%), could only be recrystallised as the thf solvate 6-Sr-(thf). The detailed protocols for the syntheses of all complexes are provided in the SI, while key data are collated in Table 1. All complexes are moderately to very soluble in chlorinated solvents and in thf, but they do not dissolve in diethyl ether nor in aliphatic or aromatic hydrocarbons. The bis(phenolate)s 3-Ae and 4-Ae are more soluble than the bis(fluoroalkoxide)s 5-Ae and 6-Ae, while, on the whole, solubility improves with Ba $<\mathrm{Sr}<\mathrm{Ca}$. Note however that solubility proved more troublesome in the cases of the complexes 6-Ae. 

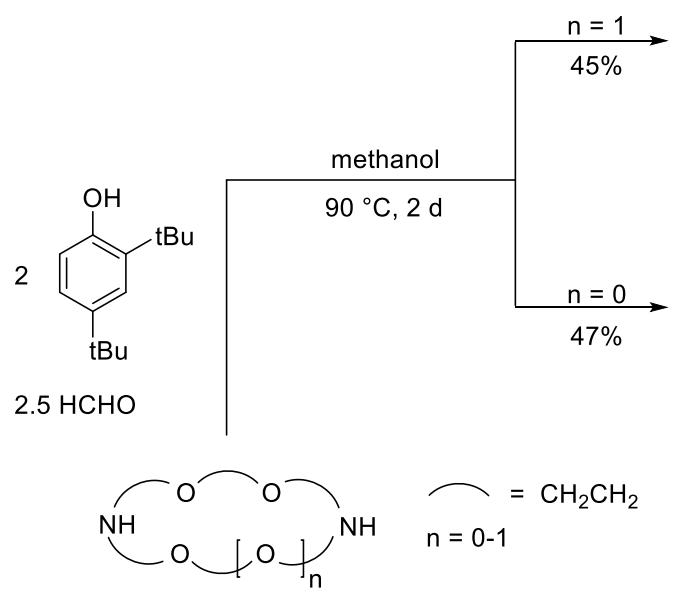

$2 \stackrel{\mathrm{O}_{\mathrm{CF}} \mathrm{CF}_{3}}{\mathrm{CF}_{3}}$

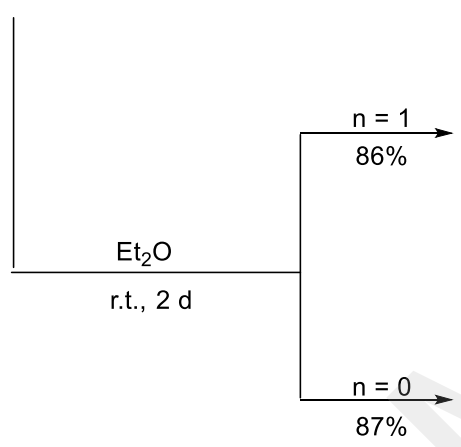

$\left[\mathrm{Ae}\left\{\mathrm{N}\left(\mathrm{SiMe}_{3}\right)_{2}\right\}_{2} \cdot(\mathrm{thf})_{2}\right.$

$-2 \mathrm{HN}\left(\mathrm{SiMe}_{3}\right)_{2}$

-2 thf
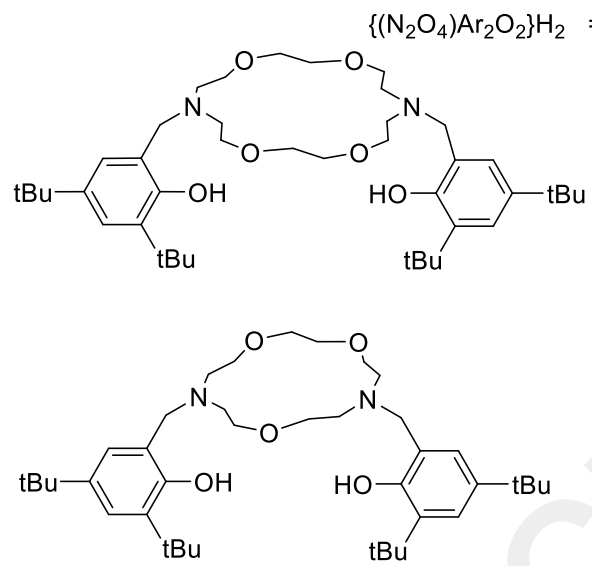

$\left\{\left(\mathrm{N}_{2} \mathrm{O}_{3}\right) \mathrm{Ar}_{2} \mathrm{O}_{2}\right\} \mathrm{H}_{2}=4-\mathrm{H}_{2}$

$\left\{\left(\mathrm{N}_{2} \mathrm{O}_{4}\right) \mathrm{R}_{2}^{\mathrm{F}} \mathrm{O}_{2}\right\} \mathrm{H}_{2}=\mathbf{5}-\mathrm{H}_{2}$
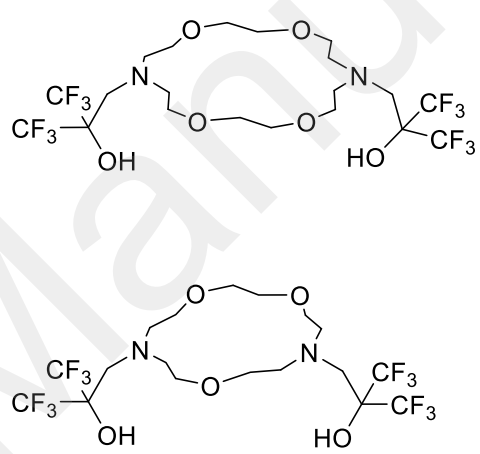

$\left\{\left(\mathrm{N}_{2} \mathrm{O}_{3}\right) \mathrm{R}_{2}{ }_{2} \mathrm{O}_{2}\right\} \mathrm{H}_{2}=6-\mathrm{H}_{2}$

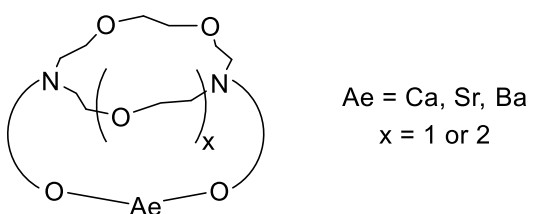

$$
\begin{array}{llll}
3-\mathrm{H}_{2} & \mathbf{5}-\mathrm{H}_{2} & {\left[\left\{\left(\mathrm{~N}_{2} \mathrm{O}_{4}\right) \mathrm{Ar}_{2} \mathrm{O}_{2}\right\} \mathrm{Ae}\right]=\mathbf{3}-\mathrm{Ae}} & {\left[\left\{\left(\mathrm{N}_{2} \mathrm{O}_{4}\right) \mathrm{R}_{2} \mathrm{O}_{2}\right\} \mathrm{Ae}\right]=\mathbf{5}-\mathrm{Ae}} \\
\mathbf{4}-\mathrm{H}_{2} & 6-\mathrm{H}_{2} & {\left[\left\{\left(\mathrm{~N}_{2} \mathrm{O}_{3}\right) \mathrm{Ar}_{2} \mathrm{O}_{2}\right\} \mathrm{Ae}\right]=4-\mathrm{Ae}} & {\left[\left\{\left(\mathrm{N}_{2} \mathrm{O}_{3}\right) \mathrm{R}^{\mathrm{F}}{ }_{2} \mathrm{O}_{2}\right\} \mathrm{Ae}\right]=\mathbf{6}-\mathrm{Ae}}
\end{array}
$$

Scheme 1. Synthesis of the proligands $3-\mathrm{H}_{2}$ to $6-\mathrm{H}_{2}$ and of the Ae complexes 3-Ae to 6-Ae $(\mathrm{Ae}=\mathrm{Ca}, \mathrm{Sr}, \mathrm{Ba})$.

The NMR data for the series of complexes 3-Ae to 6-Ae were recorded in thf- $d_{8}$ or dichloromethane$d_{2}$. The bis(phenolate)s 3-Ae and 4-Ae provided ${ }^{1} \mathrm{H}$ and ${ }^{13} \mathrm{C}\left\{{ }^{1} \mathrm{H}\right\}$ NMR spectra with overall excellent resolution. Due to their lower solubility probably stemming from some level of aggregation in solution, the NMR spectra are substantially less resolved for the bis(fluoroalkoxide)s 5-Ae and 6-Ae, especially for the latter series; besides, the fluoroalkoxides show greater dynamic behaviour in solution. Still, in their ${ }^{13} \mathrm{C}\left\{{ }^{1} \mathrm{H}\right\}$ NMR spectra recorded at room temperature, the expected resonances for $C F_{3}$ and $C\left(\mathrm{CF}_{3}\right)_{2}$ carbons atoms are detectable. For instance, in the ${ }^{13} \mathrm{C}\left\{{ }^{1} \mathrm{H}\right\}$ NMR spectra of 5-Ca, they are respectively located at 127.23 
(quadruplet, ${ }^{1} J_{\mathrm{C}-\mathrm{F}}=296 \mathrm{~Hz}$ ) and 83.18 (heptet, ${ }^{2} J_{\mathrm{C}-\mathrm{F}}=25 \mathrm{~Hz}$ ) ppm. As in the proligands $5-\mathrm{H}_{2}$, each of the complexes 5-Ae gives rise to a sole resonance, a sharp singlet, in the region -78 to $-79 \mathrm{ppm}$ of the ${ }^{19} \mathrm{~F}$ NMR spectrum, hence indicating systematic NMR equivalence of all fours $\mathrm{CF}_{3}$ groups in these compounds. On the other hand, the ${ }^{19} \mathrm{~F}$ NMR spectra for complexes 6-Ae show more diversity. The calcium complex 6-Ca gives rise to two ill-resolved quadruplets of equal intensities at $\delta_{19 \mathrm{~F}}=-79.0$ and $-79.4 \mathrm{ppm}$. Complexes 6$\mathrm{Sr} \cdot($ thf) and 6-Ba built around larger and more electropositive metals give rise to complex NMR patterns presumed to reflect the formation of aggregates and participation in fluxional processes in solution. For instance, the multiple resonances in the ${ }^{19} \mathrm{~F}\left\{{ }^{1} \mathrm{H}\right\}$ NMR spectra of 6-Sr and 6-Ba tend to merge into a wellresolved singlet at high temperature (S55-S56).

Table 1. Summary of alkaline-earth complexes synthesised in this work.

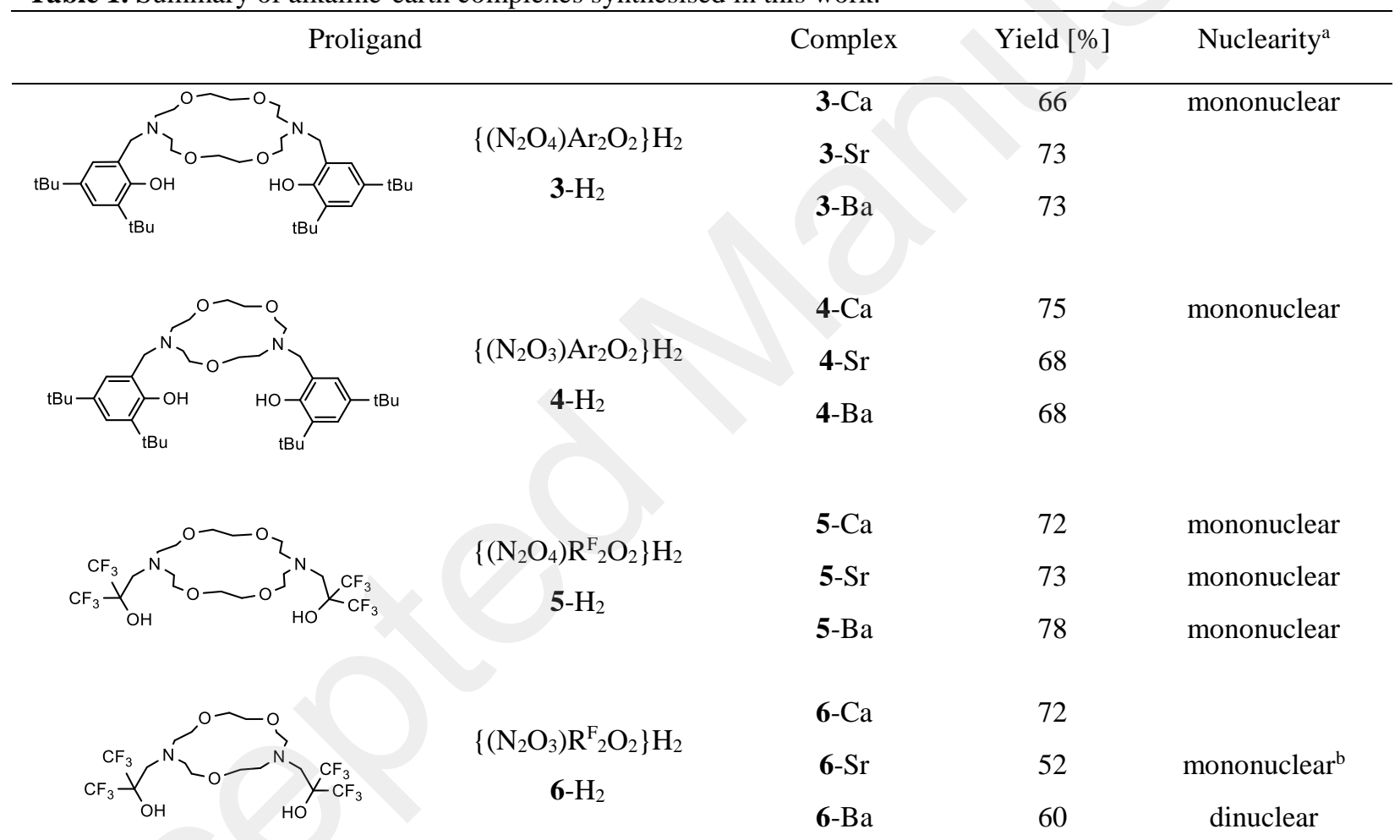

${ }^{\mathrm{a}}$ Nuclearity in the molecular solid state, as determined by X-ray diffraction crystallography. ${ }^{\mathrm{b}}$ Crystallised as the thf adduct 6-Sr.(thf).

Specific mention must be made about the ability of these new complexes to withstand hydrolysis. When attempting to grow thf-free crystals of 6-Sr (vide infra), a small crop of single crystals of the adduct 6$\mathrm{Sr} \cdot\left(\mathrm{H}_{2} \mathrm{O}\right)$, i.e. the aqua analogue of 6-Sr·(thf), were serendipitously isolated. The fact that the $\mathrm{Sr}-\mathrm{O}_{\text {alkoxide }}$ bonds in this complex resisted hydrolysis in the presence of (at least) one equivalent of water in the crystal lattice suggested the bulk sample was not overly sensitive towards moisture. This assessment was confirmed 
upon monitoring by ${ }^{1} \mathrm{H}$ NMR of solution of 4-Ba and 6-Ba in thf- $d_{8}$ regularly exposed to air over a period of days. Both compounds proved stable, as no sign of degradation was detected in by ${ }^{1} \mathrm{H}$ NMR (S58-S59). The sole change was the appearance of a sharp singlet at $2.51 \mathrm{ppm}$ assigned to $\mathrm{H}_{2} \mathrm{O}$; its intensity gradually increased with longer exposure to aerobic atmosphere. The phenolato and fluoroalkoxo moieties in these compounds are insufficiently basic to deprotonate water under dilute conditions, as their intrinsic low basicity is not compensated by other thermodynamic considerations that could drive the equilibrium forward, e.g. the subsequent formation of oxoclusters.

The molecular solid-state structures of several of the complexes were established by X-ray diffraction crystallography. Complex 3-Ca crystallised as a $C_{2}$-symmetric, eight-coordinate monomer (Figure 2), where all heteroatoms in the macrocyclic core bind to the dication. The Ca1-O11 interatomic distance to the formerly $\sigma$-bonded $\mathrm{O}_{\text {phenolate }}$ atoms $(2.2449(11) \AA$ ) is much shorter than that to the oxygen $\pi$-donors in the macrocyclic core $(\mathrm{Ca} 1-\mathrm{O} 2=2.6167(13)$ and $\mathrm{Ca} 1-\mathrm{O} 5=2.5054(11) \AA)$. It compares well with those in the dimeric $\left[\mathrm{Ca}\left\{\mathrm{Me}_{2} \mathrm{NC}_{2} \mathrm{H}_{4} \mathrm{~N}\left(\mathrm{CH}_{2}-3,5-\mathrm{tBu}_{2}-\mathrm{C}_{6} \mathrm{H}_{2} \mathrm{O}-2\right) 2\right\}\right]_{2}\left(2.1817(16)\right.$ and 2.2488(15) $\AA$ ), ${ }^{2 d}$ or those in the monomeric, five-coordinate $\left[\mathrm{Ca}\left\{\mathrm{O}-2,6-\mathrm{tBu}_{2}-4-\mathrm{Me}_{-} \mathrm{C}_{6} \mathrm{H}_{2}\right\}_{2} \cdot(\mathrm{thf})_{3}\right](2.201(6)$ and $2.210(6) \AA) .{ }^{20}$ Note the very wide N8-Ca1-N8' angle $\left(164.03(6)^{\circ}\right)$ and, in contrast, the narrow O11-Ca1-O11' angle with the $\mathrm{O}_{\text {phenolate }}$ atoms $\left(98.30(6)^{\circ}\right)$ indicative of relative spatial proximity of the phenolates. The four oxygen atoms in the macrocycle are nearly coplanar, whereas the two nitrogen atoms are located 1.8881(13) A above the mean plane determined by O2, O2', O5 and O5' (Figure 3). The $\mathrm{Ca}^{2+}$ cation sits above the distorted macrocyclic pocket (1.5209(3) $\AA$ above the best average O2-O5-O2'-O5' plane), while the two phenolates are also located on the same side of the macrocycle. These general structural features are shared with all other Ae complexes described here (vide infra). A summary of crystallographic data is provided further in Table 2.

The structure of $\left[\left\{\left(\mathrm{N}_{2} \mathrm{O}_{3}\right) \mathrm{Ar}_{2} \mathrm{O}_{2}\right\} \mathrm{Ca}\right](4-\mathrm{Ca})$ is depicted in Figure 4. It forms a $C_{1}$-symmetric sevencoordinate monomeric complex where, again, the metal ion and the two $\mathrm{O}_{\text {phenolate }}$ atoms, $\mathrm{O} 21$ and $\mathrm{O} 41$, are located above and on the same side of the macrocyclic pocket. The Ca1-O21 and Ca1-O41 interatomic distances in 4-Ca, 2.2274(9) and 2.2540(9) $\AA$, are essentially identical to those in 3-Ca. Likewise, the range of distances to the heteroatoms in the macrocycle is rather broad (Ca1-N = 2.5690(11)-2.7380(11) $\AA$ and Ca1- $\mathrm{O}_{\text {macrocycle }}=2.4740(9)-2.5130(10) \AA$ ) but their average values are commensurate with those in 3-Ca. The angles around the metal involving $\mathrm{O}_{\text {phenolate }}$ atoms in 4-Ca $\left(\mathrm{O} 21-\mathrm{Ca} 1-\mathrm{O} 41=96.11(4)^{\circ}\right)$ is also very similar to that in 3-Ca. Overall, the diminution from four to three $\mathrm{O}_{\text {macrocycle }}$ atoms on going from 3-Ca to 4Ca bears little influence on the key metric parameters. 


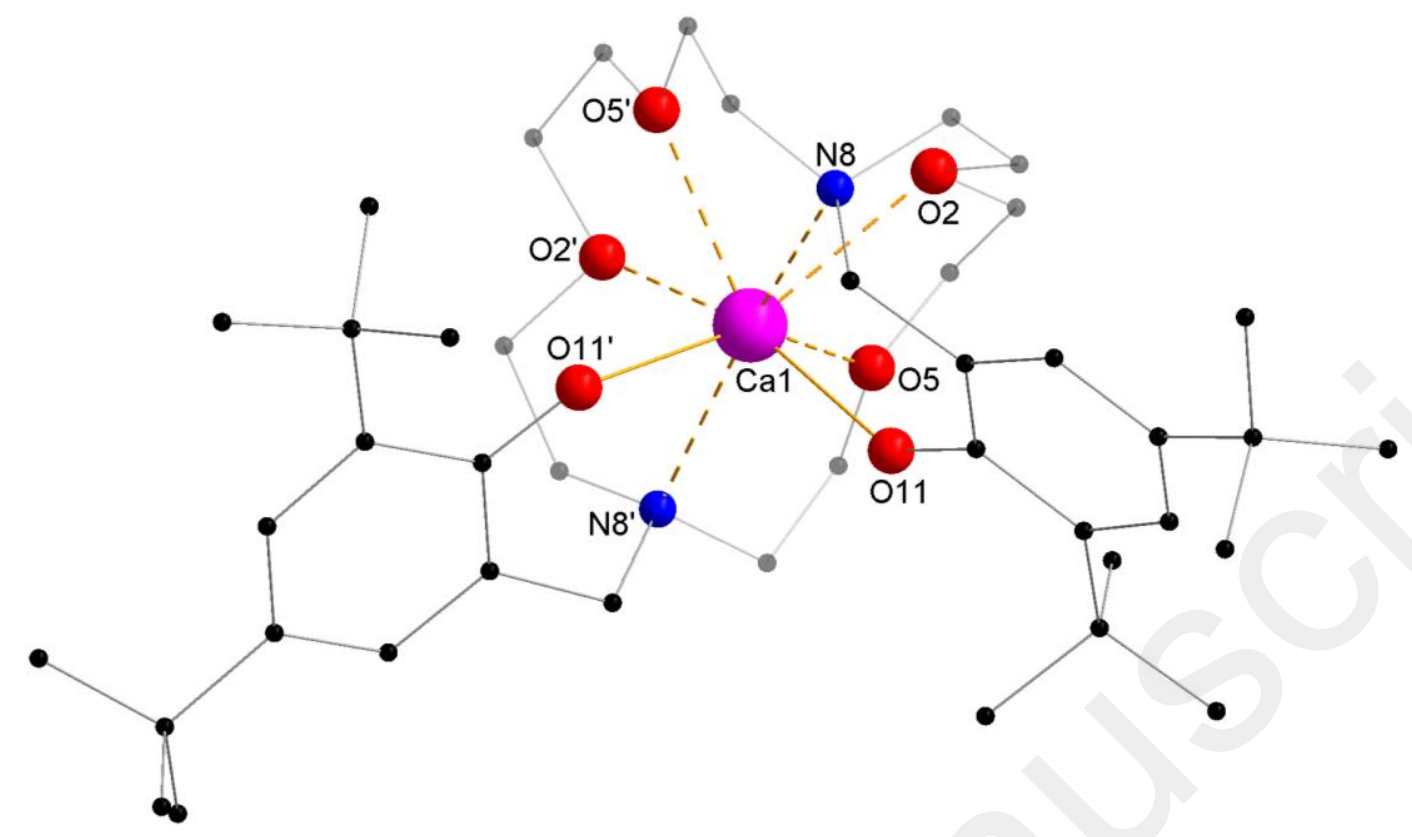

Figure 2. Representation of the molecular solid-state structure of $\left[\left\{\left(\mathrm{N}_{2} \mathrm{O}_{4}\right) \mathrm{Ar}_{2} \mathrm{O}_{2}\right\} \mathrm{Ca}\right](3-\mathrm{Ca}) . \mathrm{H}$ atoms omitted for clarity. Selected interatomic distances $(\AA)$ and angles $\left({ }^{\circ}\right)$ : Ca1-N8 $=2.6430(13)$, Ca1-O2 $=2.6167(13)$, Ca1-O5 = 2.5054(11), Ca1-O11 = 2.2449(11); N8-Ca1-N8' = 164.03(6), O11-Ca1-O11' = 98.30(6). Symmetry transformation: $\mathrm{x}+1,-\mathrm{y}+1,-\mathrm{z}+1 / 2 ; \mathrm{T}=[-1,0,0]$.

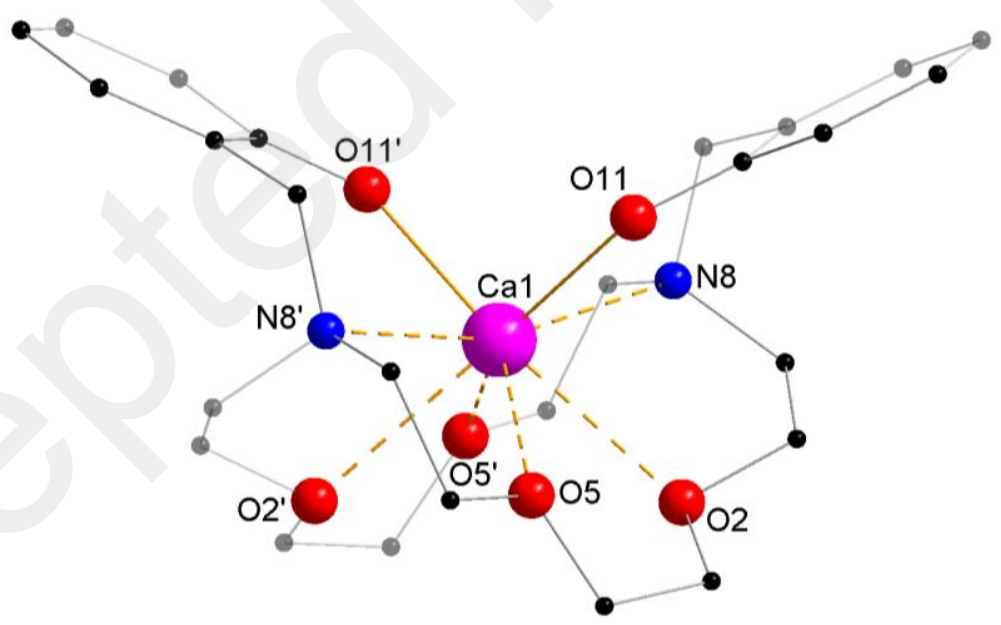

Figure 3. Simplified view of the molecular solid-state structure of $\left[\left\{\left(\mathrm{N}_{2} \mathrm{O}_{4}\right) \mathrm{Ar}_{2} \mathrm{O}_{2}\right\} \mathrm{Ca}\right](3-\mathrm{Ca})$, showing the positions of the $\mathrm{Ca} 1, \mathrm{~N} 8 / \mathrm{N} 8$ ' and $\mathrm{O} 11 / \mathrm{O} 11$ ' atoms with respect to the mean plane defined by O2-O5-O2'-O5'. $\mathrm{H}$ atoms and tBu groups removed for clarity. Distance to the mean plane ( $\mathrm{A})$ : Ca1, 1.5209(3); N8, 1.8881(13); O11, 2.9894(11). 


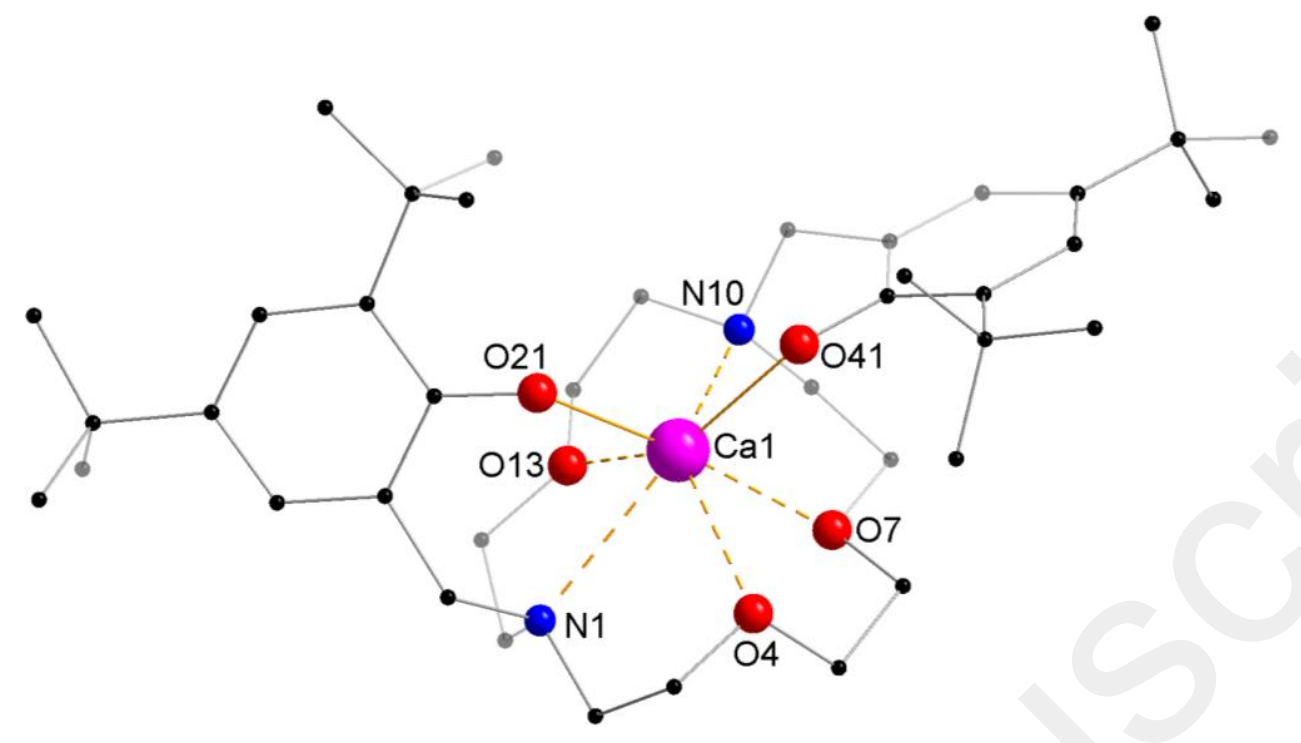

Figure 4. Representation of the molecular solid-state structure of $\left[\left\{\left(\mathrm{N}_{2} \mathrm{O}_{3}\right) \mathrm{Ar}_{2} \mathrm{O}_{2}\right\} \mathrm{Ca}\right]$ (4-Ca). $\mathrm{H}$ atoms and noninteracting thf molecule omitted for clarity. Selected interatomic distances $(\AA)$ and angles $\left(^{\circ}\right)$ : Ca1-N1 = 2.7380(11), $\mathrm{Ca} 1-\mathrm{N} 10=2.5690(11), \mathrm{Ca} 1-\mathrm{O} 4=2.4740(9), \mathrm{Ca} 1-\mathrm{O} 7=2.5130(10), \mathrm{Ca} 1-\mathrm{O} 13=2.4747(9), \mathrm{Ca} 1-\mathrm{O} 21=2.2274(9), \mathrm{Ca} 1-$ $\mathrm{O} 41=2.2540(9) ; \mathrm{N} 1-\mathrm{Ca} 1-\mathrm{N} 10=128.40(3), \mathrm{O} 21-\mathrm{Ca} 1-\mathrm{O} 41=96.11(4)$.

Like its bis(phenolate) congener 3-Ca, the calcium bis(fluoroalkoxide) $\left[\left\{\left(\mathrm{N}_{2} \mathrm{O}_{4}\right) \mathrm{R}_{2}{ }_{2} \mathrm{O}_{2}\right\} \mathrm{Ca}\right](5-\mathrm{Ca})$ is an eight-coordinate $C_{2}$-symmetric monomer, where all heteroatoms bind to the metal centre (Figure 5). The two complexes share many structural features, including the positioning of the metal and the two $\mathrm{O}_{\text {alkoxide }}$ atoms above the macrocyclic backbone. However, unlike in $3-\mathrm{Ca}$, the four $\mathrm{O}_{\text {macrocycle }}$ atoms are far from being coplanar. Instead, two $\mathrm{O}_{\text {macrocycle }}(\mathrm{O} 3$ and $\mathrm{O} 3$ ') and the two nitrogen atoms define a best average plane, from which, at a distance of $0.3766(5) \AA$, the metal is very close. This observation suggests greater flexibility and lesser steric constraint in the bis(fluoroalkoxide) ligand framework compared to its bis(phenolate) analogue. The Ca1-O1 interatomic distance to the $\mathrm{O}_{\text {alkoxide }}$ in 5-Ca $(2.2548(12) \AA)$ is near-identical to that in 3-Ca. The N1-Ca1-N1' angle in 5-Ca of $173.77(7)^{\circ}$ is also very wide. Only the O1-Ca1-O1' angle, $111.20(7)^{\circ}$, is substantially different to the equivalent one in $3-\mathrm{Ca}\left(98.30(6)^{\circ}\right)$. There is no indication for the presence of $\mathrm{Ca} \cdots \mathrm{F}$ interactions in the complex. ${ }^{21}$ 


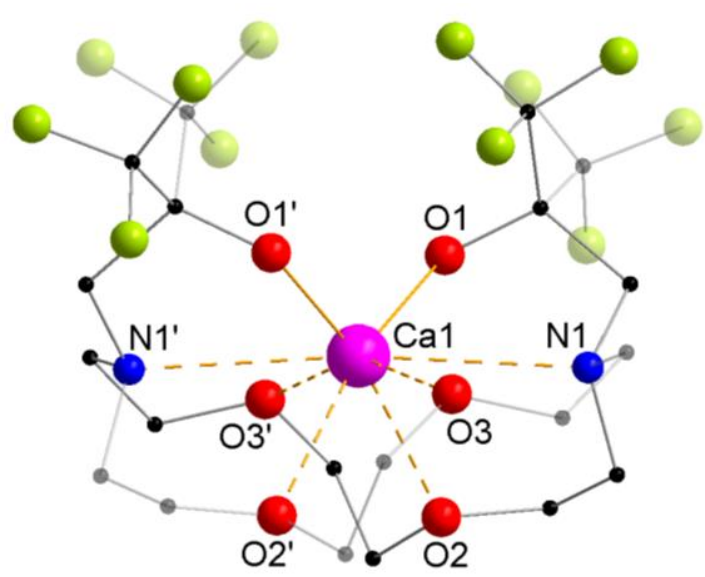

Figure 5. Representation of the molecular solid-state structure of $\left[\left\{\left(\mathrm{N}_{2} \mathrm{O}_{4}\right) \mathrm{R}_{2} \mathrm{O}_{2}\right\} \mathrm{Ca}\right](5-\mathrm{Ca})$. $\mathrm{H}$ atoms omitted for clarity. Selected interatomic distances $(\AA)$ and angles $\left({ }^{\circ}\right)$ : Ca1-O1 $=2.2548(12), \mathrm{Ca} 1-\mathrm{O} 2=2.5302(13), \mathrm{Ca} 1-\mathrm{O} 3=$ 2.5984(12), Ca1-N1 = 2.8724(15); O1-Ca1-O1' $=111.20(7)$, N1-Ca1-N1' $=173.77(7)$. Symmetry transformation: $-\mathrm{x}$, $\mathrm{y},-\mathrm{z}+1 / 2 ; \mathrm{T}=[1,0,0]$.

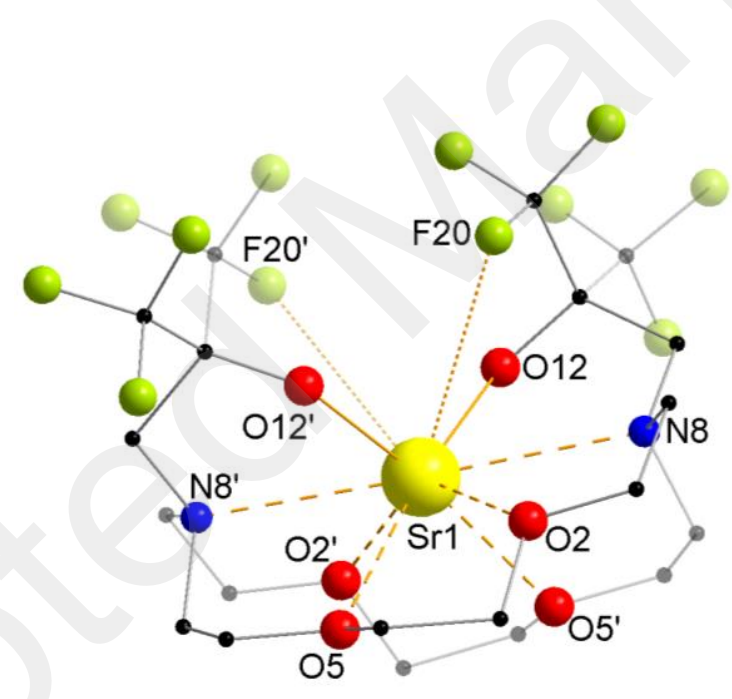

Figure 6. Representation of the molecular solid-state structure of $\left[\left\{\left(\mathrm{N}_{2} \mathrm{O}_{4}\right) \mathrm{R}_{2} \mathrm{~F}_{2} \mathrm{O}_{2}\right\} \mathrm{Sr}\right](5-\mathrm{Sr})$. H atoms omitted for clarity. Selected interatomic distances $(\AA)$ and angles $\left({ }^{\circ}\right)$ : Sr1-N8 $=2.8542(11)$, Sr1-O2 $=2.7172(9)$, Sr1-O5 $=$ 2.7297(9), Sr1-O12 = 2.4279(9), Sr1-F20 = 3.1724(10); O12-Sr1-O12' = 116.59(5), N8-Sr1-N8' = 178.68(4). Symmetry transformations: $-\mathrm{x}, \mathrm{y},-\mathrm{z}+1 / 2 ; \mathrm{T}=[1,0,0]$.

The structure of the strontium bis(fluoroalkoxide) $\left[\left\{\left(\mathrm{N}_{2} \mathrm{O}_{4}\right) \mathrm{R}_{2} \mathrm{~F}_{2} \mathrm{O}_{2}\right\} \mathrm{Sr}\right](5-\mathrm{Sr})$ resembles that of 5-Ca (Figure 6). It also forms an eight-coordinate $C_{2}$-symmetric monometallic compound, where the metal dication actually sits well above the distorted macrocyclic core. The Sr1-O12 interatomic distance to the $\mathrm{O}_{\text {alkoxide }}$ atom of 2.4279(9) $\AA$ is greater than the pertaining one in 5-Ca, but the increase is well in line with the difference of ionic radii between the $\mathrm{Sr}^{2+}$ and $\mathrm{Ca}^{2+}$ dication ( $r_{\text {ionic }}=1.18$ and $1.00 \AA$, respectively). The 
N8-Sr1-N8' angle $\left(178.68(4)^{\circ}\right)$ is almost perfectly linear. The main difference between the two complexes is the presence of two stabilising Sr $\cdots$ F intramolecular contacts in $\mathbf{5}-\mathrm{Sr}$, which is a likely expression of the enhancement of electrophilicity of the metallic dication of going from calcium to strontium. The deliberate introduction of this type of secondary interactions through ligand design in Ae molecular architectures is motivated by their ability to stabilise the resulting highly electrophilic complexes. ${ }^{18 a, 18 c, 21,22} \mathrm{The} \mathrm{Sr}-\mathrm{F} 20$ and Sr-F20' distances (3.1724(10) $\AA$ ) are in the upper range for this type of $\mathrm{Sr}^{\cdots} \cdot \mathrm{F}$ interactions. ${ }^{21,23}$ For instance, at 2.731(1) and 2.865(1) $\AA$, the contacts were much shorter in the four-coordinate $\left[\mathrm{Sr}\left\{\mathrm{N}\left(\mathrm{C}_{6} \mathrm{~F}_{5}\right)_{2}\right\}_{2} \cdot(\text { thf })_{2}\right] .{ }^{23 c}$ It has now been established that the nature of these Ae $\cdots$ F interactions is chiefly electrostatic, with little covalence and negligible contribution from attractive dispersion forces. ${ }^{21}$

The eight-coordinate $\left[\left\{\left(\mathrm{N}_{2} \mathrm{O}_{4}\right) \mathrm{R}_{2}{ }_{2} \mathrm{O}_{2}\right\} \mathrm{Ba}\right](5-\mathrm{Ba})$ is isomorphous with its strontium analogue 5-Sr (Figure 7). The Ba1-O1 distance to the $\mathrm{O}_{\text {alkoxide }}$ atom in 5-Ba (2.5683(15) $\AA$ ) is ca. $0.14 \AA$ longer than that in 5-Sr, that is, the increase is essentially in line with the respective ionic radii of $\mathrm{Ba}^{2+}(1.35 \AA)$ and $\mathrm{Sr}^{2+}$ $(1.18 \AA)$. On the other hand, the two Ba $\cdots \mathrm{F}$ interactions seem stronger, with interatomic distances of only

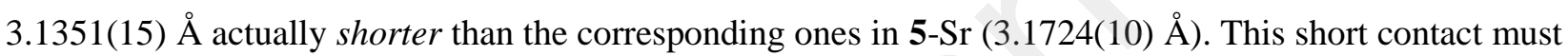
denotate the greater electrophilicity of barium in 5-Ba. Yet, these interactions range towards the upper part of similar ones observed elsewhere, albeit for complexes of overall lower coordination numbers; see, for instance, $\left[\mathrm{Ba}\left\{\mu-\mathrm{N}\left(\mathrm{C}_{6} \mathrm{~F}_{5}\right)_{2}\right\}\left\{\mathrm{N}\left(\mathrm{C}_{6} \mathrm{~F}_{5}\right)_{2}\right\} \text {.toluene }\right]_{2}(2.825(2)-3.014(3) \AA)^{21,23 a}$

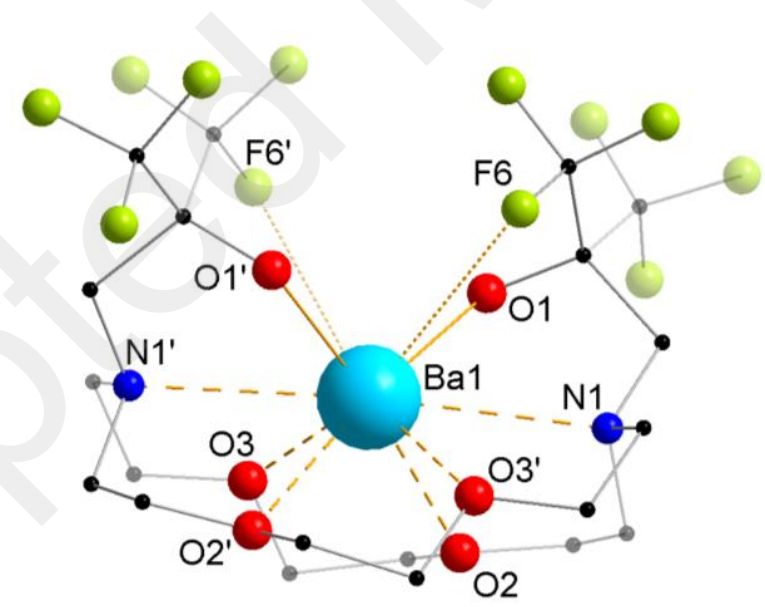

Figure 7. Representation of the molecular solid-state structure of $\left[\left\{\left(\mathrm{N}_{2} \mathrm{O}_{4}\right) \mathrm{R}_{2} \mathrm{O}_{2}\right\} \mathrm{Ba}\right](5-\mathrm{Ba})$. H atoms and noninteracting dichloromethane molecule omitted for clarity. Selected interatomic distances $(\AA)$ and angles $\left({ }^{\circ}\right)$ : Ba1-N1 = 3.0047(17), $\mathrm{Ba} 1-\mathrm{O} 1=2.5683(15), \mathrm{Ba} 1-\mathrm{O} 2=2.8527(15), \mathrm{Ba} 1-\mathrm{O} 3=2.8278(15), \mathrm{Ba} 1-\mathrm{F} 6=3.1351(15) ; \mathrm{O} 1-\mathrm{Ba} 1-\mathrm{O} 1{ }^{\prime}=$ 111.38(8), N1-Ba1-N1' = 175.42(7). Symmetry transformations: $-\mathrm{x}, \mathrm{y},-\mathrm{z}+1 / 2 ; \mathrm{T}=[1,0,0]$.

The complex [ $\left.\left\{\left(\mathrm{N}_{2} \mathrm{O}_{3}\right) \mathrm{R}_{2} \mathrm{O}_{2}\right\} \mathrm{Ba}\right](6-\mathrm{Ba})$ incorporating the smaller macrocycle with only three oxygen atoms, crystallised from thf as the centro-symmetric $O$-bridged dimer $\left[\left\{\left(\mathrm{N}_{2} \mathrm{O}_{3}\right) \mathrm{R}_{2} \mathrm{O}_{2}\right\} \mathrm{Ba}\right]_{2}$, that is, $[6-\mathrm{Ba}]_{2}$, 
as a result of the decrease of the number of heteroatoms (Figure 8). Each barium atom is eight-coordinated, with the coordination of all heteroatoms from one macrocyclic backbone being completed by bonding to one terminal and two bridging $\mathrm{O}_{\text {alkoxide }}$ atoms. Besides, each barium is further stabilised by an additional Ba $\cdots$ F interaction $(B a 1-F 30=2.998(3) \AA$ ) substantially shorter than in 5-Ba. Again, the metal centre sits well above the mean plane defined by the five heteroatoms in the macrocycle. The two interatomic distances to the bridging $\mathrm{O}_{\text {alkoxide }}$ atoms in the $\mathrm{Ba}_{2} \mathrm{O}_{2}$ central rhomboidal core are very different, 2.632(3) and 2.815(4) $\AA$. As expected for such dimers, the distance to the terminal $\mathrm{O}_{\text {alkoxide }}$ atom (Ba1-O26 $\left.=2.494(4) \AA\right)$ is much shorter than both of these. It is also shorter than the corresponding interatomic distance in the monomeric 5-Ba $\left(2.5683(15) \AA\right.$ ), which reflects a stronger bond in $[6-\mathrm{Ba}]_{2}$. Taken collectively, the comparison of the structural data for $5-\mathrm{Ba}$ and $[6-\mathrm{Ba}]_{2}$ highlights the influence of the coordination of the heteroatoms from the macrocyclic backbone. The significant intrinsic increase of electrophilicity of the metal on going from 5-Ba to 6-Ba (i.e. from 6 to 5 metal-bound macrocyclic heteroatoms) induces de facto the formation of the dimeric $[6-\mathrm{Ba}]_{2}$ with overall stronger bonds to the metal in order to compensate for the net loss of one metalcoordinated O-heteroatom. Attempts to assess the nuclearity of 6-Ba in solution by running DOSY NMR experiments were thwarted by the insufficient solubility of this complex in chlorinated solvents.

Figure 8. Representation of the molecular solid-state structure of $\left[\left\{\left(\mathrm{N}_{2} \mathrm{O}_{3}\right) \mathrm{R}_{2} \mathrm{O}_{2}\right\} \mathrm{Ba}\right]_{2}\left([6-\mathrm{Ba}]_{2}\right)$. $\mathrm{H}$ atoms and noninteracting dichloromethane molecule omitted for clarity. Selected interatomic distances $(\AA)$ and angles $\left({ }^{\circ}\right)$ : Ba1-N9 = 2.971(4), Ba1-N15 = 2.990(4), Ba1-O3 = 2.792(4), Ba1-O6 = 2.969(4), Ba1-O12 = 2.844(4), Ba1-O26 = 2.494(4), Ba1-O37 = 2.815(4), Ba1-O37’ = 2.632(3), Ba1-F30 = 2.998(3); N9-Ba1-N15 = 120.46(12). 
Finally, the solid-state structure of the thf-adduct $\left[\left\{\left(\mathrm{N}_{2} \mathrm{O}_{3}\right) \mathrm{R}_{2} \mathrm{O}_{2}\right\} \mathrm{Sr} \cdot(\right.$ thf $\left.)\right]$ (6-Sr·(thf)) was also determined. It forms a $C_{1}$-symmetric eight-coordinate monomer, where coordinative saturation around the metal is achieved by the binding of a thf molecule in addition to the multidentate ligand (Figure 9). Although single crystals were grown by recrystallisation of the analytically pure compound from a concentrated thf solution, the presence of the metal-bound solvent molecule was already detected by NMR spectroscopy of the crude product. Therefore, it originates from the precursor that was used for the synthesis of this complex, that is, the solvated $\left[\mathrm{Sr}\left\{\mathrm{N}\left(\mathrm{SiMe}_{3}\right)_{2}\right\}_{2} \cdot(\text { thf })_{2}\right]$ (vide supra). Our attempts to obtain a pure, solvent-free complex of chemical composition matching that expected for $\mathbf{6}-\mathrm{Sr}$ by using the thf-free $\left[\mathrm{Sr}\left\{\mathrm{N}\left(\mathrm{SiMe}_{3}\right)_{2}\right\}_{2}\right]_{2}$ starting material did not succeed, not least because the complex that was obtained was insoluble in solvents other than thf (presumably indicating a high degree of aggregation). Although the $\mathrm{Sr}-\mathrm{O}_{\text {alkoxide }}$ interatomic distances in 6-Sr·(thf) (2.404(2) and 2.393(2) $\AA$ ) match closely those in 5-Sr bearing the bis(fluoroalkoxide) with the wider macrocycle, the rest of the coordination sphere about the metal is actually different between these two complexes. In particular, there is no $\mathrm{Sr} \cdots \mathrm{F}$ interaction in 6-Sr-(thf), the shortest Sr-F distance being $3.5387(30) \AA$ A. Moreover, the N1-Sr1-N7 and O21-Sr1-O41 angles of $120.84(7)^{\circ}$ and $100.37(9)^{\circ}$, respectively, are much smaller than their equivalents in $\mathbf{5 - S r}$.

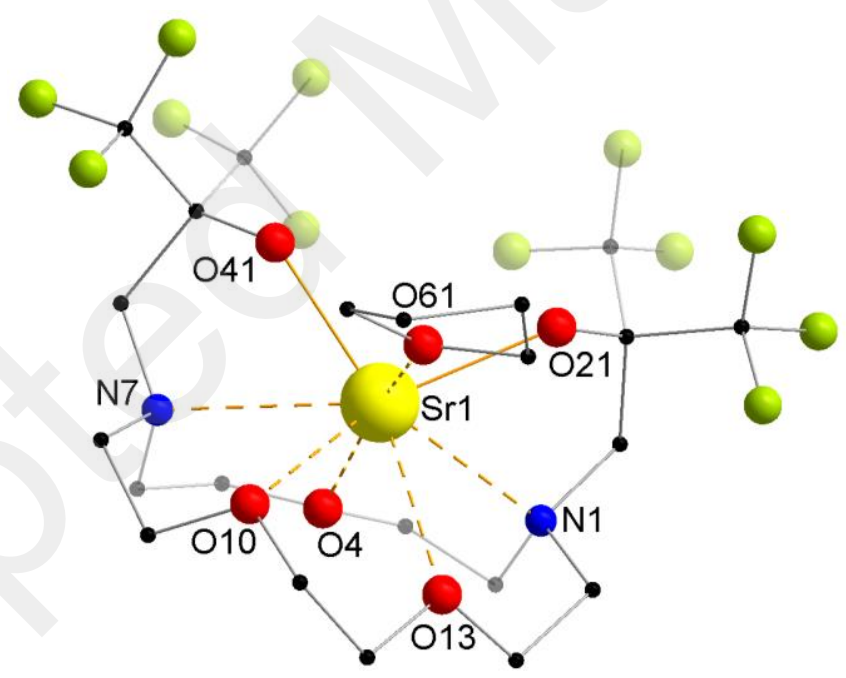

Figure 9. Representation of the molecular solid-state structure of $\left[\left\{\left(\mathrm{N}_{2} \mathrm{O}_{3}\right) \mathrm{R}_{2}{ }_{2} \mathrm{O}_{2}\right\} \mathrm{Sr} \cdot(\right.$ thf $\left.)\right](6-\mathrm{Sr} \cdot($ thf $))$. H atoms omitted for clarity. Selected interatomic distances $(\AA)$ and angles $\left({ }^{\circ}\right)$ : Sr1-N7 = 2.891(3), Sr1-N1 = 2.896(3), Sr1-O4 $=2.762(2), \mathrm{Sr} 1-\mathrm{O} 10=2.660(2), \mathrm{Sr} 1-\mathrm{O} 13=2.709(2), \mathrm{Sr} 1-\mathrm{O} 21$ = 2.404(2), $\mathrm{Sr} 1-\mathrm{O} 41=2.393(2), \mathrm{Sr} 1-\mathrm{O} 61$ = 2.5666(19); N1-Sr1-N7 = 120.84(7), O21-Sr1-O41 = 100.37(9).

A comparative summary of structural data is provided in Table 2. General trends can be extracted from the discussions above and from this table. High coordination numbers, 7 or 8 , are always observed. Most of the complexes form solvent-free monomers, except when the electrophilicity of the metal is no longer 
assuaged by the macrocyclic heteroatom $\pi$-donors; in these cases, solvent retention (as in 6-Sr·(thf) or dimerisation (as in $[6-\mathrm{Ba}]_{2}$ ) occurs. With the bis(fluoroalkoxo) ligands, intramolecular Ae $\cdots \mathrm{F}$ non-covalent interactions that impart additional thermodynamic stability to the complex are detected in three cases. Only the thf-adduct 6-Sr-(thf) does not exhibit these contacts, for reasons that are unclear at this stage; it may be that the coordination thf enforces geometrical constraints that preclude the establishment of the $\mathrm{Sr} \cdots \mathrm{F}$ interactions or that electronic saturation at the metal centre is satisfied by the thf molecule. In all cases and irrelevantly of its identity, the metal centre is not encapsulated within the macrocyclic backbone of the ligand, but sits above it. Beyond a sole mismatch between the sizes of the metal and of the macrocyclic fragment, which may anyhow not apply in the case of the smallest metal (Ca) and largest pockets (for ligands 3 and 5), this configuration may also result from geometrical considerations which force the two side-arms to be located on the same side of the macrocyclic core. Along these lines, the fact that for a given metal (calcium), the Ae- $\mathrm{N}_{\text {macrocycle }}$ interatomic distances seem much shorter in the bis(phenolate) 3-Ca than in the corresponding bis(fluoroalkoxide) 5-Ca may be significant. 
Table 2. Summary of X-ray crystallographic structural data.

\begin{tabular}{|c|c|c|c|c|c|c|c|}
\hline & {$\left[\left\{\left(\mathrm{N}_{2} \mathrm{O}_{4}\right) \mathrm{Ar}_{2} \mathrm{O}_{2}\right\} \mathrm{Ca}\right]$} & {$\left[\left\{\left(\mathrm{N}_{2} \mathrm{O}_{3}\right) \mathrm{Ar}_{2} \mathrm{O}_{2}\right\} \mathrm{Ca}\right]$} & {$\left[\left\{\left(\mathrm{N}_{2} \mathrm{O}_{4}\right) \mathrm{R}_{2} \mathrm{~F}_{2}\right\} \mathrm{Ca}\right]$} & {$\left[\left\{\left(\mathrm{N}_{2} \mathrm{O}_{4}\right) \mathrm{R}_{2} \mathrm{O}_{2}\right\} \mathrm{Sr}\right]$} & {$\left[\left\{\left(\mathrm{N}_{2} \mathrm{O}_{4}\right) \mathrm{R}_{2} \mathrm{O}_{2}\right\} \mathrm{Ba}\right]$} & 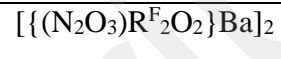 & {$\left[\left\{\left(\mathrm{N}_{2} \mathrm{O}_{3}\right) \mathrm{R}_{2} \mathrm{O}_{2}\right\} \mathrm{Sr} \cdot(\right.$ thf $\left.)\right]$} \\
\hline & 3-Ca & 4-Ca & 5-Ca & $5-\mathrm{Sr}$ & 5-Ba & {$[6-B a]_{2}$} & 6-Sr·(thf) \\
\hline$r_{\text {ionic }}(\mathrm{Ae})^{\mathrm{a}}$ & 1.00 & 1.00 & 1.00 & 1.18 & 1.35 & 1.35 & 1.18 \\
\hline Nuclearity & monomer & monomer & monomer & monomer & monomer & dimer & monomer \\
\hline Symmetry & $C_{2}$ & $C_{1}$ & $C_{2}$ & $C_{2}$ & $C_{2}$ & $C_{\mathrm{i}}$ & $C_{1}$ \\
\hline C. N. ${ }^{b}$ & 8 & 7 & 8 & 8 & 8 & 8 & 8 \\
\hline \multirow{2}{*}{$\mathrm{Ae}-\mathrm{O}_{\text {phen }}{ }^{\mathrm{c}}$} & $2.2449(11)$ & $2.2274(9)$ & - & - & - & - & - \\
\hline & - & $2.2540(9)$ & - & - & - & - & - \\
\hline \multirow[t]{3}{*}{ Ae- $\mathrm{O}_{\text {alkox. }}{ }^{\mathrm{d}}$} & - & - & $2.2548(12)$ & $2.4279(9)$ & $2.5683(15)$ & 2.494(4) terminal & $2.393(2)$ \\
\hline & - & - & - & - & - & $2.632(3)$ bridging & $2.404(2)$ \\
\hline & - & - & - & - & - & $2.815(4)$ bridging & - \\
\hline \multirow[t]{3}{*}{ Ae- $\mathrm{O}_{\text {macro }}{ }^{\mathrm{e}}$} & $2.5054(11)$ & $2.4740(9)$ & $2.5302(13)$ & $2.7172(9)$ & $2.8278(15)$ & $2.792(4)$ & $2.660(2)$ \\
\hline & $2.6167(13)$ & $2.4747(9)$ & $2.5984(12)$ & $2.7297(9)$ & $2.8527(15)$ & $2.844(4)$ & $2.709(2)$ \\
\hline & - & $2.5130(10)$ & - & - & - & $2.969(4)$ & $2.762(2)$ \\
\hline \multirow[t]{2}{*}{ Ae- $\mathrm{N}_{\text {macro }}{ }^{\mathrm{f}}$} & $2.6430(13)$ & $2.5690(11)$ & $2.8724(15)$ & $2.8542(11)$ & $3.0047(17)$ & $2.971(4)$ & $2.891(3)$ \\
\hline & - & $2.7380(11)$ & - & - & - & $2.990(4)$ & $2.896(3)$ \\
\hline $\mathrm{Ae}-\mathrm{O}_{\text {thf }}{ }^{\mathrm{g}}$ & - & - & - & - & - & - & $2.5666(19)$ \\
\hline $\mathrm{Ae}-\mathrm{F}^{\mathrm{h}}$ & - & - & - & $3.1724(10)$ & $3.1351(15)$ & $2.998(3)$ & - \\
\hline$\angle \mathrm{N}-\mathrm{Ae}-\mathrm{N}^{\prime}{ }^{\mathrm{i}}$ & $164.03(6)$ & $128.40(3)$ & 173.77(7) & $178.68(4)$ & $175.42(7)$ & $120.46(12)$ & $120.84(7)$ \\
\hline
\end{tabular}

${ }^{a}$ Ionic radius for the given Ae metals. ${ }^{b}$ Coordination number. ${ }^{c}$ Distance to $\mathrm{O}_{\text {phenolate }}$ atoms in $\AA$. ${ }^{\mathrm{d}}$ Distance to $\mathrm{O}_{\text {alkoxide }}$ atoms in $\AA$. ${ }^{\mathrm{e}}$ Distance to $\mathrm{O}_{\text {macrocycle }}$ atoms in $\AA .{ }^{\mathrm{f}}$ Distance to $\mathrm{N}_{\text {macrocycle }}$ atoms in $\AA .{ }^{\mathrm{g}}$ Distance to $\mathrm{O}_{\text {thf }}$ atom in $\AA .{ }^{\mathrm{h}}$ Distance to interacting $\mathrm{F}$ atoms in $\AA$. ${ }^{\mathrm{i}}$ Angle in degrees. 
Bond valence sum (BVS) analysis was used to estimate the contribution of Ae $\cdots$ F interactions towards the coordination sphere of the $\mathrm{Ae}^{2+}$ ions in complexes $5-\mathrm{Sr}, 5-\mathrm{Ba}$ and $[6-\mathrm{Ba}]_{2}$. This method, first introduced by Brown and developed by O'Keefe and Brese, ${ }^{24}$ uses crystallography determined interatomic distances to assess the relative contributions of the neighbouring atoms towards the coordination sphere of a given metallic centre. It has been implemented in recent years for the analysis of bonding patterns in a range of $s$ block complexes, and also to quantify the influence of non-covalent interactions, ${ }^{18 b, 25}$ Bond valences $(v)$ were calculated for 5-Sr, 5-Ba and $[6-\mathrm{Ba}]_{2}$ using equation 1 . The experimental interatomic distances $d_{\mathrm{Ae}-\mathrm{X}}$ introduced in the equation were those determined crystallographically (see Table 2), while the empirical bond valence parameters $R_{\mathrm{Ae}-\mathrm{X}}$ for $\mathrm{Sr}$ and $\mathrm{Ba}$ are tabulated values:

$v=\exp \left[\left(R_{\mathrm{Ae}-\mathrm{X}}-d_{\mathrm{Ae}-\mathrm{X}}\right) / \mathrm{B}\right]$

where $\mathrm{X}=\mathrm{O}, \mathrm{F}, \mathrm{N} ; \mathrm{B}=0.37 ; R_{\mathrm{Sr}-\mathrm{O}}=2.118, R_{\mathrm{Sr}-\mathrm{F}}=2.019, R_{\mathrm{Sr}-\mathrm{N}}=2.230, R_{\mathrm{Ba}-\mathrm{O}}=2.290, R_{\mathrm{Ba}-\mathrm{F}}=2.190$ and $R_{\mathrm{Ba}-\mathrm{N}}=2.470 .{ }^{24}$ The bond valence value, $v$, provides a quantitative estimation of the contributions of secondary Ae $\cdots$ F interactions to the coordination sphere of each $\mathrm{Ae}^{2+}$ cation. The calculated sums of bond valence values $\left(\Sigma\left(v_{\mathrm{Ae}-\mathrm{X}}\right)\right.$ for $\left.\mathrm{X}=\mathrm{N} / \mathrm{F} / \mathrm{O}\right)$ for each $\mathrm{Ae}^{2+}$ dication in $\mathbf{5}-\mathrm{Sr}, \mathbf{5}-\mathrm{Ba}$ and $[\mathbf{6}-\mathrm{Ba}]_{2}$ are displayed in Table 3. The analysis suggests that Ae $\cdots \mathrm{F}$ interactions contribute to ca. 3.8-6.4\% of the total bonding patterns in these complexes. The rest of the coordination sphere is filled by $\mathrm{Ca}-\mathrm{N}$ and $\mathrm{Ca}-\mathrm{O}$ bonds. $\mathrm{Ae} \cdots \mathrm{F}$ interactions in 5-Sr, 5-Ba and $[6-\mathrm{Ba}]_{2}$ contribute to the bonding to a level similar to that in the calcium aminoether-fluoroalkoxide $\left[\left\{\mathrm{RO}^{\mathrm{F}}\right\} \mathrm{CaN}\left(\mathrm{SiMe}_{3}\right)_{2}\right]_{2}$ where $\mathrm{Ca} \cdots \mathrm{F}$ contacts account for ca. $4.4 \%$ of the coordination around each metal centre. ${ }^{18 b}$ Yet, their magnitude is much lower than in the three-coordinate $\left[\mathrm{Ca}\left\{\mu_{2}-\mathrm{N}\left(\mathrm{SiMe}_{3}\right)_{2}\right\}\left\{\mathrm{N}\left(\mathrm{C}_{6} \mathrm{~F}_{5}\right)_{2}\right\}\right]_{2}$ and $\left[\mathrm{Ca}\left\{\mu_{2}-\mathrm{OB}\left(\mathrm{CH}\left(\mathrm{SiMe}_{3}\right)_{2}\right)_{2}\right\}\left\{\mathrm{N}\left(\mathrm{C}_{6} \mathrm{~F}_{5}\right)_{2}\right\}\right]_{2}$, two complexes where Ca $\cdots \mathrm{F}$ contacts represent $18-20 \%$ of the overall coordination sphere. ${ }^{21}$ Hence, one can legitimately conclude that, not unexpectedly, the importance of Ae $\cdots \mathrm{F}$ interactions grow as the coordination number of the complex decreases. 
Table 3. Bond valence sum analysis for the calcium complexes 5-Sr, 5-Ba and $[6-B a]_{2}$

\begin{tabular}{|c|c|c|c|c|c|c|c|c|c|}
\hline Complex & & & $d_{\mathrm{Ae}-\mathrm{N}}^{a}$ & $d_{\mathrm{Ae}-\mathrm{F}}{ }^{a}$ & $d_{\mathrm{Ae}-\mathrm{O}}{ }^{a}$ & $v_{\mathrm{Ae}-\mathrm{N}}^{b}$ & $v_{\mathrm{Ae}-\mathrm{F}}{ }^{b}$ & $v_{\mathrm{Ae}-\mathrm{O}}{ }^{b}$ & $\Sigma\left(v_{\mathrm{Ae}-\mathrm{X}}\right)$ \\
\hline$\left[\left\{\left(\mathrm{N}_{2} \mathrm{O}_{4}\right) \mathrm{R}_{2} \mathrm{~F}_{2} \mathrm{O}_{2}\right\} \mathrm{Sr}\right]$ & \multirow[t]{8}{*}{ Sr1 } & & 2.8542 & 3.1724 & 2.4279 & 0.19 & 0.04 & 0.43 & \\
\hline $5-\mathrm{Sr}$ & & & - & - & 2.7172 & - & - & 0.20 & \\
\hline One 8-coordinate $\mathrm{Sr}$ atom & & & - & - & 2.7297 & - & - & 0.19 & \\
\hline \multirow[t]{5}{*}{$C_{2}$ symmetry } & & & 2.8542 & 3.1724 & 2.4279 & 0.19 & 0.04 & 0.43 & \\
\hline & & & - & - & 2.7172 & - & - & 0.20 & \\
\hline & & & - & - & 2.7297 & - & - & 0.19 & \\
\hline & & $\Sigma\left(v_{\mathrm{Sr} 1-\mathrm{X}}\right)$ & & & & 0.38 & 0.08 & 1.64 & 2.10 \\
\hline & & $\%\left(v_{\text {Sr1-X }}\right)$ & & & & 18.1 & 3.8 & 78.1 & 100 \\
\hline$\left[\left\{\left(\mathrm{N}_{2} \mathrm{O}_{4}\right) \mathrm{R}_{2} \mathrm{O}_{2}\right\} \mathrm{Ba}\right]$ & \multirow[t]{8}{*}{ Ba1 } & & 3.0047 & 3.1351 & 2.5683 & 0.24 & 0.08 & 0.47 & \\
\hline $5-\mathrm{Ba}$ & & & - & - & 2.8278 & - & - & 0.23 & \\
\hline One 8-coordinate $\mathrm{Ba}$ atom & & & - & - & 2.8527 & - & - & 0.22 & \\
\hline \multirow[t]{5}{*}{$C_{2}$ symmetry } & & & 3.0047 & 3.1351 & 2.5683 & 0.24 & 0.08 & 0.47 & \\
\hline & & & - & - & 2.8278 & - & - & 0.23 & \\
\hline & & & - & 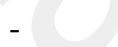 & 2.8527 & - & - & 0.22 & \\
\hline & & $\Sigma\left(v_{\mathrm{Ba} 1-\mathrm{X}}\right)$ & & & & 0.48 & 0.16 & 1.84 & 2.48 \\
\hline & & $\%\left(v_{\mathrm{Ba} 1-\mathrm{X}}\right)$ & & & & 19.3 & 6.5 & 74.2 & 100 \\
\hline$\left[\left\{\left(\mathrm{N}_{2} \mathrm{O}_{3}\right) \mathrm{R}_{2}^{\mathrm{F}_{2}} \mathrm{O}_{2}\right\} \mathrm{Ba}\right]_{2}$ & \multirow[t]{8}{*}{$\mathrm{Ba} 1=\mathrm{Ba} 1$, } & & 2.971 & 2.998 & 2.494 & 0.26 & 0.11 & 0.58 & \\
\hline 6-Ba & & & 2.990 & - & 2.632 & 0.25 & - & 0.40 & \\
\hline Two equivalent 8 -coordinate $\mathrm{Ba}$ atoms & & & - & - & 2.815 & - & - & 0.24 & \\
\hline \multirow[t]{5}{*}{$C_{\mathrm{i}}$ symmetry } & & & - & - & 2.792 & - & - & 0.26 & \\
\hline & & & - & - & 2.844 & - & - & 0.22 & \\
\hline & & & - & - & 2.969 & - & - & 0.16 & \\
\hline & & $\Sigma\left(v_{\mathrm{Ba} 1-\mathrm{X}}\right)$ & & & & 0.51 & 0.11 & 1.86 & 2.48 \\
\hline & & $\%\left(v_{\mathrm{Ba} 1-\mathrm{X}}\right)$ & & & & 20.6 & 4.4 & 75.0 & 100 \\
\hline
\end{tabular}

${ }^{a}$ Measured interatomic distances to $\mathrm{X}=\mathrm{N}, \mathrm{F}$ or $\mathrm{O}$ atoms, given in $\AA$; see Figures 6,7 and 8 and Table 2 for detail. ${ }^{b}$ Bond valence contribution for atom $\mathrm{X} .{ }^{c}$ Sum of all contributions for the different atoms: $X=N, F$ and $O$. 
Several attempts were made to gauge the Lewis acidity in complexes 3-Ae/6-Ae. All things remaining equal otherwise, for a given ligand framework, the Lewis acidity was expected to decrease gradually from $\mathrm{Ca}$ to $\mathrm{Sr}$ owing to the increase of the volume at constant electric charge.

Childs' method involves the use of an enone such cyclohex-2-en-1-one, with its relatively soft $p \pi-p \pi$ $\mathrm{C}=\mathrm{O}$ bond, as a Lewis basic probe; it is meant to be well suited to Lewis acids with a soft character. ${ }^{26}$ Upon coordination to a Lewis acid, a variation of the ${ }^{1} \mathrm{H}$ NMR chemical shift for the hydrogen atom in position 3 is observed; to a greater Lewis acidity corresponds a greater modification of the chemical shift. However, in the case of our hard Lewis acidic complexes, this analysis performed in the recommended dichloromethane- $d_{2}$ indicated no variation of the chemical shifts associated to the cyclohex-2-en-1-one.

The Gutmann-Beckett method is another available empirical tool to assess the Lewis acidity of various compounds. It relies on the utilisation of the comparatively harder $\mathrm{Et}_{3} \mathrm{P}=\mathrm{O}$, with its more ionic $d \pi-p \pi \mathrm{P}=\mathrm{O}$ bond, as a probe for ${ }^{31} \mathrm{P}\left\{{ }^{1} \mathrm{H}\right\}$ NMR spectroscopy. ${ }^{27}$ The interaction of this hard Lewis base with a Lewis acid (e.g. adduct formation) induces a quantifiable deshielding of the resonance associated to $\mathrm{Et}_{3} P=\mathrm{O}$ compared to that of the free molecule $\left(\delta_{31 \mathrm{P}}=50.35 \mathrm{ppm}\right.$ in dichloromethane- $\left.d_{2}\right)$. The Gutmann-Beckett method is well suited to boranes, ${ }^{28}$ although it has also been employed on other occasions for metal-based complexes ${ }^{29}$ or organic molecules. ${ }^{30}$ Yet, in our case, the analysis proved largely uninformative. It provided fully reproducible but apparently erratic results without discernible trend based either on metal or ligand. Similar observations have been made when applying this tool to other metal complexes,${ }^{29}$ in particular with the alkaline earths, ${ }^{29 c, 29 d}$ and the question of the real value of these measurements is now debated. The sole learning from these measurements considered collectively was that complexes 3-Ae/6-Ae seem overall to be poorly to moderately Lewis acidic, with deshielding of the ${ }^{31} \mathrm{P}$ chemical shift of the resonance for $\mathrm{Et}_{3} P=\mathrm{O}$ confined to $0-3$ ppm. ${ }^{27,28,31}$

Finally, DFT computations were used to determine the global electrophilicity index (GEI) for selected complexes, following a method introduced by Parr and recently implemented by Stephan. ${ }^{32}$ For a given molecule, the GEI method provides an acidity metric that quantifies the intrinsic electrophilicity. It relies on the determination of the chemical hardness (abbreviated $\eta$ ), i.e. the energy gap between HOMO and LUMO orbitals, and of the Mulliken electronegativity $(\chi)$. The GEI, abbreviated as $\omega$ and reported in electronvolts, can be calculated using the set of equations (2)-(4):

$$
\begin{aligned}
& \omega=\chi^{2} / 2 \eta \\
& \chi=-1 / 2\left[\mathrm{E}_{\text {HOMO }}+\mathrm{E}_{\mathrm{LUMO}}\right] \\
& \eta=\left[\mathrm{E}_{\mathrm{LUMO}}-\mathrm{E}_{\text {Hомо }}\right]
\end{aligned}
$$

DFT computations were carried out for the bis(fluoroalkoxide)s 5-Ca and 5-Sr, two complexes bearing the same ligand that have been structurally characterised and that have the same (8) coordination number. 
Structure optimisation reproduced well the experimental data. The more demanding analysis for the heavier barium congener, 5-Ba, could not be performed with the high level of theory requested for the analysis. Two different methods were used, as described by Stephan and co-workers. In the first one, geometry optimisation was carried out on Gaussian 09 using the BP86 functional and the def2-TZVP basis set; the energy was recalculated at the MP2-def2-TZVPP level. ${ }^{32 b}$ For the second protocol, geometry optimisation was performed on Gaussian 09 using the B3LYP functional and the def2-TZVP basis set. ${ }^{32 c}$ The viability of our computations was validated by independently reproducing the results reported for model compounds, $\mathrm{B}\left(2,6-\mathrm{F}_{2}-\mathrm{C}_{6} \mathrm{H}_{3}\right)_{3}$ (GEI: calculated, $0.832 \mathrm{eV}$; literature, $\left.{ }^{32 b} 0.833 \mathrm{eV}\right)$ and $\mathrm{BF}_{3}($ GEI: calculated, $1.451 \mathrm{eV}$; literature, ${ }^{32 c} 1.476 \mathrm{eV}$ ). GEI values of 0.628 and $0.812 \mathrm{eV}$ were calculated for 5-Ca with the first and second methodologies, respectively; the corresponding values for 5-Sr were 0.737 and $0.892 \mathrm{eV}$. Although the GEI values cannot be compared across different families of compounds, these results suggest that (i) both of these related complexes are overall weakly acidic, and (ii) counter-intuitively, the strontium complex 5-Sr seems to be a stronger Lewis acid than 5-Ca built on the smaller metal.

\section{Concluding remarks}

A large number of calcium, strontium and barium complexes bearing structurally related dianionic, multidentate bis(phenolato)s or bis(fluoroalkoxide)s anchored around diaza-macrocyclic cores have been prepared, and many have been structurally characterised. Subtle variations of the structural patterns were detected upon tuning the identity of the alkaline earth and/or that of the ligand, including dimerisation or the establishment of electrostatic intramolecular Ae $\cdots \mathrm{F}$ interactions. These structural considerations were seen as indications that the complexes might display varying levels of Lewis acidity. Yet, we have been unable to gauge reliably this parameter using several common methods,${ }^{33}$ although, considered as a whole, the different measurements concurred to indicate overall low acidity across all families of complexes from 3-Ae to 6-Ae. ${ }^{34}$ The intrinsic Lewis acidity of Ae elements in these complexes is most likely inhibited by the high number of metal-bound $\pi$-donating heteroatoms. Our current efforts to design low-nuclearity Ae complexes of greater Lewis acidity and electrophilicity involve less heteroatom-rich bis(fluoroalkoxide)s and bis(phenolate)s built around $N, N^{\prime}$-dimethylethylenediamine and $N, N^{\prime}, N$ ''-trimethyldiethylenetriamine. These compounds, which unquestionably induce greater values of Gutmann-Beckett and GEI acidity measurements as well as different structural patterns from the compounds detailed herein, will be described in an upcoming report.

\section{Conflicts of interest}

There are no conflicts of interest to declare. 


\section{Acknowledgements}

The authors thank the ANR for funding (ANR-17-CE07-0003-01) and for the provision of a PhD studentship to J. H. We are grateful to Univ Rennes, Universite Paris-Saclay, CNRS and Ecole Polytechnique for their support of this work.

\section{Experimental section}

Selected examples of proligand and complex syntheses are given herein. For the complete synthetic details and characterisation of all complexes, see the Supporting Information.

\section{General procedures}

All manipulations were performed under an inert atmosphere by using standard Schlenk techniques or in a dry, solvent-free glovebox (Jacomex; $\mathrm{O}_{2}<1$ ppm, $\mathrm{H}_{2} \mathrm{O}<5$ ppm). $\mathrm{CaI}_{2}, \mathrm{SrI}_{2}$ and $\mathrm{BaI}_{2}$ beads (99.999\%, Aldrich) were used as purchased. Solvents (thf, $\mathrm{Et}_{2} \mathrm{O}$, pentane and toluene) were purified and dried (water contents all in the range 1-5 ppm) over alumina columns (MBraun SPS). Thf was further distilled under argon from $\mathrm{Na} /$ benzophenone prior to use. Deuterated solvents (Eurisotop, Saclay, France) were stored in sealed ampoules over activated $3 \AA$ molecular sieves and degassed by several freeze-thaw cycles. $\left.\left[\mathrm{Ae}\left\{\mathrm{N}\left(\mathrm{SiMe}_{3}\right)_{2}\right\}_{2} \text {. (thf }\right)_{2}\right]$ and $\left[\mathrm{Ae}\left\{\mathrm{N}\left(\mathrm{SiMe}_{3}\right)_{2}\right\}_{2}\right]_{2}$ precursors were prepared following a published literature procedure. All NMR spectra were recorded with Bruker AM-400 or AM-500 spectrometers; assignment of the resonances was assisted by $1 \mathrm{D}\left({ }^{1} \mathrm{H},{ }^{13} \mathrm{C}\right.$ $\left.\left\{{ }^{1} \mathrm{H}\right\}\right)$ and 2D (COSY, HMBC, and HSQC) NMR experiments. Elemental analysis is provided for the proligands; attempts to obtain the reliable combustion analysis for the complexes were not successful.

$\left\{\left(\mathbf{N}_{2} \mathrm{O}_{3}\right) \mathrm{Ar}_{2} \mathrm{O}_{2}\right\} \mathrm{H}_{2}\left(4-\mathrm{H}_{2}\right)$ : Formaldehyde $\left(0.86 \mathrm{ml}, 37\right.$ wt. \% in $\left.\mathrm{H}_{2} \mathrm{O}, 11.45 \mathrm{mmol}\right)$ was added to a mixture of 2,4-di-tert-butyl-phenol (1.89 g, $9.16 \mathrm{mmol})$ and 4,10-diaza-15-crown-5-ether (1.00 g, $4.58 \mathrm{mmol})$ in methanol $(10 \mathrm{ml})$. The mixture was refluxed overnight. The resulting heavy oil was dried to constant weight, and then recrystallised from hot methanol (reflux). Yield: $1.40 \mathrm{~g}, 47 \%$. The title compound shows good solubility in aliphatic solvents, diethyl ether, and chlorinated solvents.

${ }^{1} \mathrm{H}$ NMR $\left(400 \mathrm{MHz}, \mathrm{C}_{6} \mathrm{D}_{6}, 298 \mathrm{~K}\right): \delta=10.93(\mathrm{~s}, 2 \mathrm{H}, \mathrm{OH}), 7.52\left(\mathrm{~d},{ }^{4} \mathrm{~J}_{\mathrm{HH}}=2.4 \mathrm{~Hz}, 2 \mathrm{H}\right.$, arom-H), $6.93\left(\mathrm{~d},{ }^{4} J_{\mathrm{HH}}=2.4 \mathrm{~Hz}, 2 \mathrm{H}, \operatorname{arom}-H\right), 3.46\left(\mathrm{~s}, 4 \mathrm{H}, \mathrm{ArCH}_{2} \mathrm{~N}\right), 3.38\left(\mathrm{t},{ }^{3} J_{\mathrm{HH}}=5.1 \mathrm{~Hz}, 4 \mathrm{H}\right.$, 
$\left.\mathrm{OCH}_{2} \mathrm{CH}_{2} \mathrm{O}\right), 3.34\left(\mathrm{~s}, 4 \mathrm{H}, \mathrm{OCH}_{2} \mathrm{CH}_{2} \mathrm{~N}\right), 3.32\left(\mathrm{t},{ }^{3} J_{\mathrm{HH}}=5.4 \mathrm{~Hz}, 4 \mathrm{H}, \mathrm{OCH}_{2} \mathrm{CH}_{2} \mathrm{~N}\right), 2.64(\mathrm{~s}, 4 \mathrm{H}$, $\left.\mathrm{NCH}_{2} \mathrm{CH}_{2} \mathrm{O}\right), 2.57\left(\mathrm{t},{ }^{3} \mathrm{JH}_{\mathrm{HH}}=5.1 \mathrm{~Hz}, 4 \mathrm{H}, \mathrm{NCH}_{2} \mathrm{CH}_{2} \mathrm{O}\right), 1.73\left(\mathrm{~s}, 18 \mathrm{H}, p-\mathrm{C}\left(\mathrm{CH}_{3}\right)_{3}\right), 1.38(\mathrm{~s}, 18 \mathrm{H}, o-$ $\left.\mathrm{C}\left(\mathrm{CH}_{3}\right)_{3}\right) \mathrm{ppm}$.

${ }^{13} \mathrm{C}\left\{{ }^{1} \mathrm{H}\right\}$ NMR $\left(100 \mathrm{MHz}, \mathrm{C}_{6} \mathrm{D}_{6}, 298 \mathrm{~K}\right): \delta=203.72(i-\mathrm{COH}), 155.30\left(p-\mathrm{CC}\left(\mathrm{CH}_{3}\right)_{3}\right), 140.58(o-$ $\left.\mathrm{CC}\left(\mathrm{CH}_{3}\right)_{3}\right), 136.14\left(o_{-} \mathrm{CCH}_{2} \mathrm{~N}\right), 123.85(m-\mathrm{CH}), 123.12(m-\mathrm{CH}), 122.55(m-\mathrm{CH}), 70.85$ $\left(\mathrm{OCH}_{2} \mathrm{CH}_{2} \mathrm{O}\right), 69.39\left(\mathrm{OCH}_{2} \mathrm{CH}_{2} \mathrm{~N}\right), 68.64\left(\mathrm{OCH}_{2} \mathrm{CH}_{2} \mathrm{~N}\right), 60.40\left(\mathrm{ArCH}_{2} \mathrm{~N}\right), 54.60\left(\mathrm{NCH}_{2} \mathrm{CH}{ }_{2} \mathrm{O}\right)$, $54.33\left(\mathrm{NCH}_{2} \mathrm{CH}_{2} \mathrm{O}\right), 35.38\left(p-C\left(\mathrm{CH}_{3}\right)_{3}\right), 34.39\left(o-C\left(\mathrm{CH}_{3}\right)_{3}\right), 32.06\left(p-\mathrm{C}\left(\mathrm{CH}_{3}\right)_{3}\right), 30.10\left(o-\mathrm{C}\left(\mathrm{CH}_{3}\right)_{3}\right)$ ppm.

Anal. calc for $\mathrm{C}_{40} \mathrm{H}_{66} \mathrm{~N}_{2} \mathrm{O}_{5}\left(654.98\right.$ g.mol $\left.{ }^{-1}\right)$ : C 73.35, H 10.16, N 4.28\%; found C 73.1, H 10.1, N $4.2 \%$.

HR-MS: m/z: $655.504[\mathrm{M}+\mathrm{H}]^{+}$; calc for $\mathrm{C}_{40} \mathrm{H}_{67} \mathrm{~N}_{2} \mathrm{O}_{5}: 655.50445 ; \mathrm{m} / \mathrm{z}: 677.4854[\mathrm{M}+\mathrm{Na}]^{+}$; calc for $\mathrm{C}_{40} \mathrm{H}_{66} \mathrm{~N}_{2} \mathrm{O}_{5} \mathrm{Na}$ : 677.48639 .

$\left\{\left(\mathbf{N}_{2} \mathbf{O}_{3}\right) \mathbf{R}^{\mathrm{F}_{2}} \mathbf{O}_{2}\right\} \mathbf{H}_{\mathbf{2}}\left(\mathbf{6}-\mathrm{H}_{2}\right)$ : A solution of 2,2-bis(trifluoromethyl)oxirane (1.25 ml, $\left.11.45 \mathrm{mmol}\right)$ in diethyl ether $(10 \mathrm{ml})$ was added dropwise to a solution of 4,10-diaza-15-crown-5-ether (1.00 g, $4.58 \mathrm{mmol})$ in diethyl ether $(10 \mathrm{ml})$ at $0{ }^{\circ} \mathrm{C}$. The reaction mixture was warmed slowly to room temperature and stirred for 2 days. The volatile fraction was then removed under vacuum, and the title product was obtained as a white powder. Yield: $2.30 \mathrm{~g}$, $87 \%$. It displays excellent solubility in all common organic solvents, including aliphatic hydrocarbons.

${ }^{1} \mathrm{H}$ NMR (400 MHz, $\left.\mathrm{C}_{6} \mathrm{D}_{6}, 298 \mathrm{~K}\right): \delta=6.62(\mathrm{~s}, 2 \mathrm{H}, \mathrm{OH}), 3.20\left(\mathrm{~s}, 4 \mathrm{H}, \mathrm{OCH}_{2} \mathrm{CH}_{2} \mathrm{O}\right), 3.04(\mathrm{~m}, 8 \mathrm{H}$, $\left.\mathrm{OCH}_{2} \mathrm{CH}_{2} \mathrm{~N}\right), 2.62\left(\mathrm{~s}, 4 \mathrm{H}, \mathrm{C}\left(\mathrm{CF}_{3}\right)_{2} \mathrm{CH}_{2}\right), 2.40-2.31\left(\mathrm{~m}, 8 \mathrm{H}, \mathrm{NCH}_{2} \mathrm{CH}_{2} \mathrm{O}\right)$.

${ }^{13} \mathrm{C}\left\{{ }^{1} \mathrm{H}\right\}$ NMR $\left(100 \mathrm{MHz}, \mathrm{C}_{6} \mathrm{D}_{6}, 298 \mathrm{~K}\right): \delta=125.90\left(\mathrm{q},{ }^{1} J_{\mathrm{CF}}=285.0 \mathrm{~Hz}, C_{3}\right), 73.46$ (hept, ${ }^{2} J_{\mathrm{CF}}=$ $\left.28.5 \mathrm{~Hz}, C\left(\mathrm{CF}_{3}\right)_{2}\right), 70.25\left(\mathrm{OCH}_{2} \mathrm{CH}_{2} \mathrm{O}\right), 68.92\left(\mathrm{OCH}_{2} \mathrm{CH}_{2} \mathrm{~N}\right), 68.49\left(\mathrm{OCH}_{2} \mathrm{CH}_{2} \mathrm{~N}\right), 57.34$

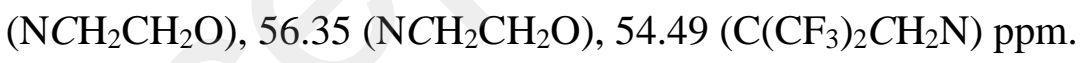

${ }^{19} \mathrm{~F}\left\{{ }^{1} \mathrm{H}\right\}$ NMR (376 MHz, $\left.\mathrm{C}_{6} \mathrm{D}_{6}, 298 \mathrm{~K}\right): \delta=-77.19$ (s, 12F, $\left.\mathrm{C} F_{3}\right) \mathrm{ppm}$.

Anal. calc. for $\mathrm{C}_{18} \mathrm{H}_{26} \mathrm{~N}_{2} \mathrm{O}_{5} \mathrm{~F}_{12}\left(578.4\right.$ g.mol $\left.{ }^{-1}\right)$ : C 37.38, H 4.53, N 4.84\%; found C 37.9, H 4.2, N $4.9 \%$.

HR-MS: m/z: $601.4552[\mathrm{M}+\mathrm{Na}]^{+}$; calc for $\mathrm{C}_{18} \mathrm{H}_{26} \mathrm{~N}_{2} \mathrm{O}_{5} \mathrm{~F}_{12} \mathrm{Na}: 601.15423$.

[\{( $\left.\left.\left.\mathbf{N}_{2} \mathbf{O}_{4}\right) \mathbf{A r}_{2} \mathbf{O}_{2}\right\} \mathbf{C a}\right]$ (3-Ca): A solution of $\mathbf{3}-\mathrm{H}_{2}(0.30 \mathrm{~g}, 0.42 \mathrm{mmol})$ in difluorobenzene (10 ml) was added to a solution of $\left.\left[\mathrm{Ca}\left\{\mathrm{N}\left(\mathrm{SiMe}_{3}\right)_{2}\right\}_{2} \text {. (thf }\right)_{2}\right](0.22 \mathrm{~g}, 0.42 \mathrm{mmol})$ in difluorobenzene (15 
$\mathrm{ml})$. The reaction mixture was stirred for $2 \mathrm{~h}$ and the volatiles were removed under vacuum. The resulting white powder was washed with pentane $(3 \times 5 \mathrm{ml})$ and the product was dried under vacuum to constant weight. Yield: $0.21 \mathrm{~g}, 66 \%$. The title compound shows good solubility in chlorinated solvents, thf and 1,2-difluorobenzene. However, it is insoluble in aliphatic solvents and diethyl ether.

${ }^{1} \mathrm{H}$ NMR $\left(400 \mathrm{MHz}\right.$, thf- $\left.d_{8}, 298 \mathrm{~K}\right): \delta=7.02\left(\mathrm{~d},{ }^{4} J_{\mathrm{HH}}=2.7 \mathrm{~Hz}, 2 \mathrm{H}\right.$, arom- $\left.H\right), 6.72\left(\mathrm{~d},{ }^{4} J_{\mathrm{HH}}=2.6\right.$ $\mathrm{Hz}, 2 \mathrm{H}, \operatorname{arom}-\mathrm{H}), 4.76\left(\mathrm{~d},{ }^{4} \mathrm{~J}_{\mathrm{HH}}=11.1 \mathrm{~Hz}, 2 \mathrm{H}, \mathrm{ArCH}_{2} \mathrm{~N}\right), 4.01-3.90\left(\mathrm{~m}, 4 \mathrm{H}, \mathrm{OCH}_{2} \mathrm{CH}_{2} \mathrm{O}\right), 3.72$ (m, $\left.2 \mathrm{H}, \mathrm{OCH}_{2} \mathrm{CH}_{2} \mathrm{O}\right), 3.64-3.60\left(\mathrm{~m}, 4 \mathrm{H}, \mathrm{OCH}_{2} \mathrm{CH}_{2} \mathrm{~N}\right), 3.55-3.43\left(\mathrm{~m}, 4 \mathrm{H}, \mathrm{OCH}_{2} \mathrm{CH}_{2} \mathrm{~N}\right), 3.41-3.31$ $\left(\mathrm{m}, 2 \mathrm{H}, \mathrm{NCH}_{2} \mathrm{CH}_{2} \mathrm{O}\right), 3.12-3.05\left(\mathrm{~m}, 2 \mathrm{H}, \mathrm{NCH}_{2} \mathrm{CH}_{2} \mathrm{O}\right), 2.94\left(\mathrm{~d},{ }^{4} \mathrm{~J}_{\mathrm{HH}}=11.2 \mathrm{~Hz}, 2 \mathrm{H}, \mathrm{ArCH}_{2} \mathrm{~N}\right)$, 2.76-2.53 (m, 4H, $\left.\mathrm{NCH}_{2} \mathrm{CH}_{2} \mathrm{O}\right), 2.32\left(\mathrm{~m}, 2 \mathrm{H}, \mathrm{OCH}_{2} \mathrm{CH}_{2} \mathrm{O}\right), 1.49\left(\mathrm{~s}, 18 \mathrm{H}, p-\mathrm{C}\left(\mathrm{CH}_{3}\right)_{3}\right), 1.20(\mathrm{~s}, 18 \mathrm{H}$, $\left.o-\mathrm{C}\left(\mathrm{CH}_{3}\right)_{3}\right) \mathrm{ppm}$.

${ }^{13} \mathrm{C}\left\{{ }^{1} \mathrm{H}\right\}$ NMR $\left(100 \mathrm{MHz}\right.$, thf- $\left.d_{8}, 298 \mathrm{~K}\right): \delta=167.76(i-C \mathrm{O}), 134.99\left(p-C\left(\mathrm{CH}_{3}\right)_{3}\right), 130.20(o-$ $\left.\mathrm{CC}\left(\mathrm{CH}_{3}\right)_{3}\right), 127.11(m-\mathrm{CH}), 124.77\left(o-\mathrm{CCH}_{2} \mathrm{~N}\right), 123.33(m-\mathrm{CH}), 71.90\left(\mathrm{OCH}_{2} \mathrm{CH}_{2} \mathrm{~N}\right), 70.62$ $\left(\mathrm{OCH}_{2} \mathrm{CH}_{2} \mathrm{~N}\right), 69.41\left(\mathrm{NCH}_{2} \mathrm{CH}_{2} \mathrm{O}\right), 69.35\left(\mathrm{OCH}_{2} \mathrm{CH}_{2} \mathrm{O}\right), 64.99\left(\mathrm{ArCH}_{2} \mathrm{~N}\right), 57.81\left(\mathrm{OCH}_{2} \mathrm{CH}_{2} \mathrm{O}\right)$, $\left.\left.50.79\left(\mathrm{NCH}_{2} \mathrm{CH}_{2} \mathrm{O}\right), 35.79\left(p-C\left(\mathrm{CH}_{3}\right)_{3}\right), 34.38\left(o-C\left(\mathrm{CH}_{3}\right)_{3}\right), 32.80\left(o-\mathrm{C}_{\left(C H_{3}\right.}\right)_{3}\right), 30.49\left(p-\mathrm{C}_{\left(C H_{3}\right.}\right)_{3}\right)$ ppm.

[\{( $\left.\left.\left.\mathrm{N}_{2} \mathrm{O}_{3}\right) \mathrm{Ar}_{2} \mathrm{O}_{2}\right\} \mathrm{Ca}\right]$ (4-Ca): Following the same protocol described for 3-Ca, the complex 4-Ca was obtained by reacting $(0.30 \mathrm{~g}, 0.46 \mathrm{mmol})$ of $4-\mathrm{H}_{2}$ in diethyl ether $(10 \mathrm{ml})$ with a solution of $\left.\left[\mathrm{Ca}\left\{\mathrm{N}\left(\mathrm{SiMe}_{3}\right)_{2}\right\}_{2} \text {. (thf }\right)_{2}\right](0.23 \mathrm{~g}, 0.46 \mathrm{mmol})$ in diethyl ether $(10 \mathrm{ml})$. Yield: $0.24 \mathrm{~g}, 75 \%$. The title compound shows poor solubility in aliphatic solvents and high solubility in thf and chlorinated solvents.

${ }^{1} \mathrm{H}$ NMR $\left(400 \mathrm{MHz}\right.$, thf- $\left.d_{8}, 298 \mathrm{~K}\right): \delta=7.03\left(\mathrm{~d},{ }^{4} J_{\mathrm{HH}}=2.8 \mathrm{~Hz}, 2 \mathrm{H}\right.$, arom-H), $6.73\left(\mathrm{~d},{ }^{4} J_{\mathrm{HH}}=2.7\right.$ $\mathrm{Hz}, 2 \mathrm{H}, \operatorname{arom}-H), 4.04\left(\mathrm{~d},{ }^{4} \mathrm{~J}_{\mathrm{HH}}=11.2 \mathrm{~Hz}, 2 \mathrm{H}, \mathrm{ArCH}_{2} \mathrm{~N}\right), 3.86-3.65\left(\mathrm{~m}, 8 \mathrm{H}, \mathrm{OCH}_{2} \mathrm{CH}_{2} \mathrm{~N}\right), 3.55$ $\left(\mathrm{m}, 2 \mathrm{H}, \mathrm{OCH}_{2} \mathrm{CH}_{2} \mathrm{O}\right), 3.33\left(\mathrm{~m}, 2 \mathrm{H}, \mathrm{OCH}_{2} \mathrm{CH}_{2} \mathrm{O}\right), 3.24\left(\mathrm{~d},{ }^{4} \mathrm{~J}_{\mathrm{HH}}=11.3 \mathrm{~Hz}, 2 \mathrm{H}, \mathrm{ArCH}_{2} \mathrm{~N}\right), 3.01(\mathrm{~m}$, $\left.2 \mathrm{H}, \mathrm{NCH}_{2} \mathrm{CH}_{2} \mathrm{O}\right), 2.77\left(\mathrm{~m}, 2 \mathrm{H}, \mathrm{NCH}_{2} \mathrm{CH}_{2} \mathrm{O}\right), 2.63\left(\mathrm{~m}, 2 \mathrm{H}, \mathrm{NCH}_{2} \mathrm{CH}_{2} \mathrm{O}\right), 2.51(\mathrm{~m}, 2 \mathrm{H}$, $\left.\mathrm{NCH}_{2} \mathrm{CH}_{2} \mathrm{O}\right), 1.40\left(\mathrm{~s}, 18 \mathrm{H}, p-\mathrm{C}\left(\mathrm{CH}_{3}\right)_{3}\right), 1.23$ (s, 18H, o- $\left.\left(\mathrm{CH}_{3}\right)_{3}\right) \mathrm{ppm}$.

${ }^{13} \mathrm{C}\left\{{ }^{1} \mathrm{H}\right\} \mathrm{NMR}\left(100 \mathrm{MHz}\right.$, thf- $\left.d_{8}, 298 \mathrm{~K}\right): \delta=167.33(i-C \mathrm{O}), 136.25\left(p-C \mathrm{C}\left(\mathrm{CH}_{3}\right)_{3}\right), 130.65(o-$ $\left.\mathrm{CC}\left(\mathrm{CH}_{3}\right)_{3}\right), 126.22\left(o-\mathrm{CCH}_{2} \mathrm{~N}\right), 123.67(m-\mathrm{CH}), 123.64(m-\mathrm{CH}), 70.47\left(\mathrm{OCH}_{2} \mathrm{CH}_{2} \mathrm{O}\right), 70.17$ $\left(\mathrm{OCH}_{2} \mathrm{CH}_{2} \mathrm{O}\right), 68.50\left(\mathrm{OCH}_{2} \mathrm{CH}_{2} \mathrm{~N}\right), 66.49\left(\mathrm{OCH}_{2} \mathrm{CH}_{2} \mathrm{~N}\right), 63.20\left(\mathrm{ArCH}_{2} \mathrm{~N}\right), 55.15\left(\mathrm{NCH}_{2} \mathrm{CH}_{2} \mathrm{O}\right)$, 
$\left.52.14\left(\mathrm{NCH}_{2} \mathrm{CH}_{2} \mathrm{O}\right), 36.04\left(p-C\left(\mathrm{CH}_{3}\right)_{3}\right), 34.42\left(o-C\left(\mathrm{CH}_{3}\right)_{3}\right), 32.81\left(o-\mathrm{C}\left(\mathrm{CH}_{3}\right)_{3}\right), 30.92\left(p-\mathrm{C}_{(} \mathrm{CH}_{3}\right)_{3}\right)$ ppm.

[\{( $\left.\left.\left.\mathbf{N}_{2} \mathbf{O}_{4}\right) \mathbf{R}^{\mathrm{F}_{2}} \mathbf{O}_{2}\right\} \mathbf{B a}\right]$ (5-Ba): Following the same protocol described for 5-Ca, the complex 5-Ba was obtained by reacting $(0.30 \mathrm{~g}, 0.48 \mathrm{mmol})$ of $5-\mathrm{H}_{2}$ in diethyl ether $(10 \mathrm{ml})$ with a solution of $\left[\mathrm{Ba}\left\{\mathrm{N}\left(\mathrm{SiMe}_{3}\right)_{2}\right\}_{2} .(\mathrm{thf})_{2}\right](0.29 \mathrm{~g}, 0.48 \mathrm{mmol})$ in diethyl ether $(10 \mathrm{ml})$. Yield: $0.29 \mathrm{~g}, 78 \%$. The title compound is only very mildly soluble in chlorinated solvents.

${ }^{1} \mathrm{H}$ NMR (400 MHz, $\left.\mathrm{CD}_{2} \mathrm{Cl}_{2}, 298 \mathrm{~K}\right): \delta=3.86-3.71\left(\mathrm{~m}, 8 \mathrm{H}, \mathrm{OCH}_{2} \mathrm{CH}_{2} \mathrm{O}\right), 3.64-3.59(\mathrm{~m}, 8 \mathrm{H}$, $\mathrm{OCH}_{2} \mathrm{CH}_{2} \mathrm{~N}$ ), 2.81 (s, $\left.4 \mathrm{H}, \mathrm{C}\left(\mathrm{CF}_{3}\right)_{2} \mathrm{CH}_{2}\right), 2.73\left(\mathrm{~m}, 8 \mathrm{H}, \mathrm{NCH}_{2} \mathrm{CH}_{2} \mathrm{O}\right) \mathrm{ppm}$.

${ }^{13} \mathrm{C}\left\{{ }^{1} \mathrm{H}\right\}$ NMR $\left(100 \mathrm{MHz}, \mathrm{CD}_{2} \mathrm{Cl}_{2}, 298 \mathrm{~K}\right): \delta=127.35$ (q, $\left.{ }^{1} J_{\mathrm{CF}}=295.6 \mathrm{~Hz}, C \mathrm{CF}_{3}\right), 82.42$ (hept, ${ }^{2} J_{\mathrm{CF}}$ $\left.=28.5 \mathrm{~Hz}, C\left(\mathrm{CF}_{3}\right)_{2}\right), 70.89\left(\mathrm{OCH}_{2} \mathrm{CH}_{2} \mathrm{O}\right), 69.63\left(\mathrm{OCH}_{2} \mathrm{CH}_{2} \mathrm{~N}\right), 59.16\left(\mathrm{C}_{\left.\left(\mathrm{CF}_{3}\right)_{2} \mathrm{CH}_{2}\right),}, 55.85\right.$ $\left(\mathrm{NCH}_{2} \mathrm{CH}_{2} \mathrm{O}\right)$ ppm.

${ }^{19} \mathrm{~F}\left\{{ }^{1} \mathrm{H}\right\}$ NMR (376 MHz, $\left.\mathrm{CD}_{2} \mathrm{Cl}_{2}, 298 \mathrm{~K}\right): \delta=-78.10\left(\mathrm{~s}, 12 \mathrm{~F}, \mathrm{CF}_{3}\right) \mathrm{ppm}$.

[\{( $\left.\left.\left(\mathrm{N}_{2} \mathrm{O}_{3}\right) \mathbf{R}^{\mathrm{F}_{2}} \mathrm{O}_{2}\right\} \mathrm{Sr}\right]$ (6-Sr): Following the same protocol described for 5-Ca, the complex 6-Sr was obtained by reacting $(0.30 \mathrm{~g}, 0.52 \mathrm{mmol})$ of $6-\mathrm{H}_{2}$ in diethyl ether $(10 \mathrm{ml})$ with a solution of $\left.\left[\mathrm{Sr}\left\{\mathrm{N}\left(\mathrm{SiMe}_{3}\right)_{2}\right\}_{2} \text {. (thf }\right)_{2}\right](0.29 \mathrm{~g}, 0.52 \mathrm{mmol})$ in diethyl ether $(10 \mathrm{ml})$. Yield: $0.14 \mathrm{~g}, 52 \%$. The title compound presents a poor solubility in aliphatic solvents and high solubility in thf and chlorinated solvents.

${ }^{1} \mathrm{H}$ NMR (400 MHz, thf- $\left.d_{8}, 328 \mathrm{~K}\right): \delta=3.83-3.71\left(\mathrm{~m}, 6 \mathrm{H}\right.$, overlapping $\left.\mathrm{OCH}_{2} \mathrm{CH}_{2} \mathrm{~N}\right), 3.66-3.62(\mathrm{~m}$, $\left.4 \mathrm{H}, \mathrm{OCH}_{2} \mathrm{CH}_{2} \mathrm{O}\right), 3.50-3.44\left(\mathrm{~m}, 2 \mathrm{H}, \mathrm{OCH}_{2} \mathrm{CH}_{2} \mathrm{~N}\right), 2.97-2.91\left(\mathrm{~m}, 2 \mathrm{H}, \mathrm{NCH}_{2} \mathrm{CH}_{2} \mathrm{O}\right), 2.93\left(\mathrm{~d},{ }^{2} J_{\mathrm{HH}}\right.$ $\left.=14.8 \mathrm{~Hz}, 4 \mathrm{H}, \mathrm{C}\left(\mathrm{CF}_{3}\right)_{2} \mathrm{CH}_{2}\right), 2.63-2.32\left(\mathrm{~m}, 6 \mathrm{H}, \mathrm{NCH}_{2} \mathrm{CH}_{2} \mathrm{O}\right) \mathrm{ppm}$.

${ }^{13} \mathrm{C}\left\{{ }^{1} \mathrm{H}\right\}$ NMR (100 MHz, thf- $d_{8}, 298 \mathrm{~K}$ ): $\delta=128.52\left(\mathrm{q},{ }^{1} J_{\mathrm{CF}}=297.4 \mathrm{~Hz}, C \mathrm{~F}_{3}\right), 82.77$ (hept, ${ }^{2} J_{\mathrm{CF}}=$ $\left.28.5 \mathrm{~Hz}, \mathrm{C}\left(\mathrm{CF}_{3}\right)_{2}\right), 69.82\left(\mathrm{OCH}_{2} \mathrm{CH}_{2} \mathrm{O}\right), 68.88\left(\mathrm{OCH}_{2} \mathrm{CH}_{2} \mathrm{~N}\right), 59.21\left(\mathrm{C}_{\left.\left(\mathrm{CF}_{3}\right)_{2} \mathrm{CH}_{2}\right),}, 54.36\right.$ $\left(\mathrm{NCH}_{2} \mathrm{CH}_{2} \mathrm{O}\right)$ ppm.

${ }^{19} \mathrm{~F}\left\{{ }^{1} \mathrm{H}\right\}$ NMR (376 MHz, thf $\left.-d_{8}, 330 \mathrm{~K}\right): \delta=-79.85$ (s, $\left.12 \mathrm{~F}, \mathrm{C} F_{3}\right)$.

\section{Notes and references}

1 (a) S. Harder, Chem. Rev., 2010, 110, 3852; (b) M. R. Crimmin and M. S. Hill, Top. Organomet. Chem., 2013, 45, 191; (c) M. S. Hill, D. J. Liptrot and C. Weetman, Chem. Soc. Rev., 2016, 45, 972; (d) Early 
Main Group Metal Catalysis: Concepts and Reactions, ed. S. Harder, Wiley-VCH Verlag GmbH \& Co, 2020.

2 (a) Z. Zhong, P. J. Dijkstra, C. Birg, M. Westerhausen and J. Feijen, Macromolecules, 2001, 34, 3863;

(b) M. H. Chisholm, J. Gallucci and K. Phomphrai, Chem. Commun., 2003, 48; (c) M. S. Hill and P.

B. Hitchcock, Chem. Commun., 2003, 1758; (d) Y. Sarazin, R. H. Howard, D. L. Hughes, S. M. Humphrey and M. Bochmann, Dalton Trans., 2006, 340.

3 (a) A. Weeber, S. Harder, H. H. Brintzinger and K. Knoll, Organometallics, 2000, 19, 1325; (b) S. Harder, F. Feil and K. Knoll, Angew. Chem. Int. Ed., 2001, 40, 4261.

4 (a) M. R. Crimmin, I. J. Casely and M. S. Hill, J. Am. Chem. Soc., 2005, 127, 2042; (b) M. R. Crimmin, M. Arrowsmith, A. G. M. Barrett, I. J. Casely, M. S. Hill and P. A. Procopiou, J. Am. Chem. Soc., 2009, 131, 9670 .

5 (a) A. G. M. Barrett, C. Brinkmann, M. R. Crimmin, M. S. Hill, P. Hunt and P. A. Procopiou, J. Am. Chem. Soc., 2009, 131, 12906; (b) C. Brinkmann, A. G. M. Barrett, M. S. Hill and P. A. Procopiou, J. Am. Chem. Soc., 2012, 134, 2193.

6 (a) J. Spielmann, F. Buch and S. Harder, Angew. Chem. Int. Ed., 2008, 47, 9434; (b) D. Schuhknecht, C. Lhotzky, T. P. Spaniol, L. Maron and J. Okuda, Angew. Chem. Int. Ed., 2017, 56, 12367; (c) H. Bauer, M. Alonso, C. Fischer, B. Rösch, H. Elsen and S. Harder, Angew. Chem. Int. Ed., 2018, 57, 15177; (d) H. Bauer, K. Thum, M. Alonso, C. Fischer and S. Harder, Angew. Chem. Int. Ed., 2019, 58, 4248.

7 (a) F. Buch, J. Brettar and S. Harder, Angew. Chem., Int. Ed., 2006, 45, 2741; (b) P. Jochmann, J. P. Davin, T. P. Spaniol, L. Maron and J. Okuda, Angew. Chem., Int. Ed., 2012, 51, 4452.

8 (a) T. M. A. Al-Shboul, H. Görls and M. Westerhausen, Inorg. Chem. Commun., 2008, 11, 1419; (b) F. M. Younis, S. Krieck, T. M. A. Al-Shboul, H. Görls and M. Westerhausen, Inorg. Chem., 2016, 55, 4676.

9 M. R. Crimmin, A. G. M. Barrett, M. S. Hill, P. B. Hitchcock and P. A. Procopiou, Organometallics, 2007, 26, 2953.

10 (a) M. S. Hill, D. J. Liptrot, D. J. MacDougall, M. F. Mahon and T. P. Robinson, Chem. Sci., 2013, 4, 4212; (b) E. Le Coz, V. Dorcet, T. Roisnel, S. Tobisch, J.-F. Carpentier and Y. Sarazin, Angew. Chem. Int. Ed., 2018, 57, 11747.

11 (a) A. S. S. Wilson, M. S. Hill, M. F. Mahon, C. Dinoi and L. Maron, Science, 2017, 358, 1168; (b) A. S. S. Wilson, C. Dinoi, M. S. Hill, M. F. Mahon and L. Maron, Angew. Chem. Int. Ed., 2018, 57, 15500; (c) B. Rösch, T. X. Gentner, H. Elsen, C. A. Fischer, J. Langer, M. Wiesinger and S. Harder, Angew. Chem. Int. Ed., 2019, 58, 5396. 
12 D. J. Liptrot, M. Arrowsmith, A. L. Colebatch, T. J. Hadlington, M. S. Hill, G. Kociok-Köhn and M. F. Mahon, Angew. Chem. Int. Ed., 2015, 54, 15280.

13 M. D. Anker, C. E. Kefalidis, Y. Yang, J. Fang, M. S. Hill, M. F. Mahon and L. Maron, J. Am. Chem. Soc., 2017, 139, 10036.

14 (a) J. Spielmann, G. Jansen, H. Bandmann and S. Harder, Angew. Chem. Int. Ed., 2008, 47, 6290; (b) J. Spielmann and S. Harder, J. Am. Chem. Soc., 2009, 131, 5064.

15 (a) M. Niggemann and M. J. Meel, Angew. Chem. Int. Ed., 2010, 49, 3684; (b) T. Haven, G. Kubik, S. Haubenreisser and M. Niggemann, Angew. Chem. Int. Ed., 2013, 52, 4016; (c) D. Lebœuf, E. Schulz and V. Gandon, Org. Lett., 2014, 16, 6464; (d) D. Lebœuf, M. Presset, B. Michelet, C. Bour, S. Bezzenine-Lafollée and V. Gandon, Chem. Eur. J., 2015, 21, 11001; (e) D. Leboeuf, L. Marin, B. Michelet, A. Perez-Luna, R. Guillot, E. Schulz and V. Gandon, Chem. Eur. J., 2016, 22, 16165; (f) S. P. Morcillo, D. Leboeuf, C. Bour and V. Gandon, Chem. Eur. J., 2016, 22, 16974; (g) C. Qi, V. Gandon and D. Leboeuf, Angew. Chem. Int. Ed., 2018, 57, 14245; (h) S. Wang, R. Guillot, J.-F. Carpentier, Y. Sarazin, C. Bour, V. Gandon and D. Lebœuf, Angew. Chem. Int. Ed., 2020, 59, 1134.

16 B. Liu, T. Roisnel, J.-P. Guégan, J.-F. Carpentier and Y. Sarazin, Chem. Eur. J., 2012, 18, 6289.

17 J.-F. Carpentier, Dalton Trans., 2010, 39, 37.

18 (a) Y. Sarazin, B. Liu, T. Roisnel, L. Maron and J.-F. Carpentier, J. Am. Chem. Soc., 2011, 133, 9069; (b) S.-C. Roşca, T. Roisnel, V. Dorcet, J.-F. Carpentier and Y. Sarazin, Organometallics, 2014, 33, 5630; (c) S.-C. Roşca, C. Dinoi, E. Caytan, V. Dorcet, M. Etienne, J.-F. Carpentier and Y. Sarazin, Chem. Eur. J., 2016, 22, 6505.

19 (a) D. J. Darensbourg, W. Choi, P. Ganguly and C. P. Richers, Macromolecules, 2006, 39, 4374; (b) L. Clark, G. B. Deacon, C. M. Forsyth, P. C. Junk, P. Mountford, J. P. Townley and J. Wang, Dalton Trans., 2013, 42, 9294.

20 P. B. Hitchcock, M. F. Lappert, G. A. Lawless and B. Royo, J. Chem. Soc., Chem. Commun., 1990, 1141.

21 H. Roueindeji, A. Ratsifitahina, T. Roisnel, V. Dorcet, S. Kahlal, J.-Y. Saillard, J.-F. Carpentier and Y. Sarazin, Chem. Eur. J., 2019, 25, 8854.

22 W. D. Buchanan, D. G. Allis and K. Ruhlandt-Senge, Chem. Commun., 2010, 46, 4449.

23 (a) M. Gartner, H. Görls and M. Westerhausen, Dalton Trans., 2008, 1574; (b) S.-C. Roşca, V. Dorcet, T. Roisnel, J.-F. Carpentier and Y. Sarazin, Dalton Trans., 2017, 46, 14785; (c) C. A. Fischer, A. Rösch, H. Elsen, G. Ballmann, M. Wiesinger, J. Langer, C. Färber and S. Harder, Dalton Trans., 2019, 48, 6757.

24 (a) I. D. Brown and D. Altermatt, Acta Crystallogr. Sect. B, 1985, 41, 244; (b) N. E. Brese and M. O’Keefe, Acta Crystallogr. Sect. B, 1991, 47, 192; (c) I. D. Brown, Chem. Rev., 2009, 109, 6858. 
25 (a) W. D. Buchanan, E. D. Nagle and K. Ruhlandt-Senge, Main Group Chem., 2009, 8, 263; (b) J. S. Lum, L. Tahsini, J. A. Golen, C. Moore, A. L. Rheingold and L. H. Doerrer, Chem. Eur. J., 2013, 19, 6374; (c) W. D. Buchanan and K. Ruhlandt-Senge, Chem. Eur. J., 2013, 19, 10708.

26 (a) R. F. Childs, D. L. Mulholland, and A. Nixon, Can. J. Chem., 1982, 60, 801; (b) J. Davies and D. Leonori, Chem. Commun., 2014, 50, 15171.

27 (a) V. Gutmann, Coord. Chem. Rev, 1976, 18, 225; (b) M. A. Beckett, G. C. Strickland, J. R. Holland and K. Sukumar Varma, Polym., 1996, 37, 4629.

28 (a) M. A. Beckett, D. S. Brassington, S. J. Coles, M. B. Hursthouse, Inorg. Chem. Commun., 2000. 3, 530; (b) G. J. P. Britovsek, J. Ugolotti and A. J. P. White, Organometallics, 2005, 24, 1685; (c) G. C. Welch, L. Cabrera, P. A. Chase, E. Hollink, J. D. Masuda, P. Wei and D. W. Stephan, Dalton Trans., 2007, 3407; (d) I. B. Sivaev and V. I. Bregadze, Coord. Chem. Rev., 2014, 270-271, 75.

29 (a) A. E. Ashley, T. J. Herrington, G. G. Wildgoose, H. Zaher, A. L. Thompson, N. H. Rees, T. Krämer and D. O'Hare, J. Am. Chem. Soc., 2011, 133, 14727; (b) A. B. Kremer, R. J. Andrews, M. J. Milner, X. R. Zhang, T. Ebrahimi, B. O. Patrick, P. L. Diaconescu and P. Mehrkhodavandi, Inorg. Chem., 2017, 56, 1375; (c) J. Pahl, S. Brand, H. Elsen and S. Harder, Chem. Commun., 2018, 54, 8685; (d) M. Schorpp and I. Krossing, Chem. Sci., 2020, 11, 2068.

30 A. Labattut, P.-L. Tremblay, O. Moutounet and C. Y. Legault, J. Org. Chem., 2017, 82, 11891.

$31{ }^{31} \mathrm{P}$ NMR chemical shift variations of $20-40 \mathrm{ppm}$ can be expected for $\mathrm{Et}_{3} P=\mathrm{O}$ with strong Lewis acids. For instance, it is deshielded by $37.0 \mathrm{ppm}$ in the case of $\mathrm{B}\left(\mathrm{C}_{6} \mathrm{~F}_{5}\right)_{3}$, see reference $28 a$.

32 (a) R. G. Parr, L. v. Szentpály and S. Liu, J. Am. Chem. Soc., 1999, 121, 1922; (b) A. R. Jupp, T. C. Johnstone and D. W. Stephan, Dalton. Trans, 2018, 47, 7029; (c) A. R. Jupp, T. C. Johnstone and D. W. Stephan, Inorg. Chem, 2018, 57, 14764.

33 L. Greb, Chem. Eur. J., 2018, 24, 17881.

34 Note that when confronted to these first data sets, the choice to not investigate another computational method, based on the determination of the fluoride ion affinity, was made. 